\title{
A Population at Risk: Civil Commitment of Substance Abusers After Kansas v. Hendricks
}

\author{
Mara Lynn Krongard $\dagger$
}

\section{TABLE OF CONTENTS}

Introduction

I. The Development of Civil Commitment Law .................................. 117

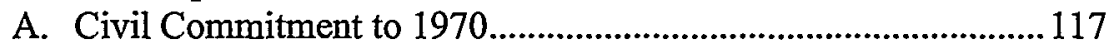

B. Backlash and the Middle Ground: The 1970 s to $1997 \ldots \ldots . . . . . . . .118$

1. Challenges to the Old Regime ............................................118

2. The Development of Modern Civil Commitment Law: 1970s to Pre-Hendricks

a. The Middle Ground: O'Connor v. Donaldson and Youngberg v. Romeo ........................................................ 121

b. Addington v. Texas .......................................................122

c. Shoring Up the Middle Ground: Foucha v. Louisiana.. 124

d. Following Suit: In re Hendricks.

II. The Doctrinal About-Face in Civil Commitment Law: Kansas $v$. Hendricks

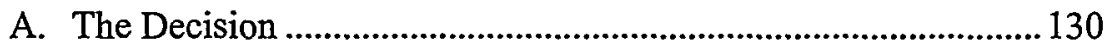

B. The Implications: An Open Invitation to Expand States' Civil Commitment Power

III. Substance Abusers: A Population at Greater Risk of Civil Commitment After Hendricks

A. The Court's Willingness to Push Constitutional Limits in the "War on Drugs".

Copyright $(1002$ California Law Review, Inc. California Law Review, Inc. (CLR) is a California nonprofit corporation. CLR and the authors are solely responsible for the content of their publications.

$\dagger$ J.D. Candidate 2002, School of Law, University of California, Berkeley (Boalt Hall); A.B., Princeton University, 1996. 1 would like to thank, first and foremost, Professor Howard Goldman of the University of Maryland School of Medicine, for the idea as well as for his support, guidance, and msight into the perspectives of the medical community on involuntary civil commitment. Without him this Comment would not have been possible. Thanks also to the 2001-02 editorial staff of the California Law Review, and especially Sarah Shaw and the Notes and Comments team, for their encouragement and editorial rigor. Finally, special thanks to Ben Shreck, for making law school especially worthwhile. 
1. The "Special Needs" Exception to the Fourth Amendment .136

2. Civil Asset Forfeiture and the Fifth Amendment ................. 139

B. Civil Commitment of "Dangerous" Substance Abusers Before and After Hendricks

1. The Existence of Specific Provisions for Substance Abusers

2. The Use of General Civil Commitment Statutes to Confine

"Dangerous" Substance Abusers Before Hendricks 143

3. The Use of General Civil Commitment Statutes to Confine "Dangerous" Substance Abusers After Hendricks 145

C. Meeting the Statutory Requirements After Hendricks: The Concept of "Dangerousness". 147

1. Substance Abuse as Danger to Self .................................... 147

2. Predictions of Dangerousness to Others ............................... 149

a. The Accuracy of Mental Health Professionals' Predictions of Dangerousness ....................................... 149

b. The Law of Dangerousness Prediction............................ 149

c. Dangerousness and Substance Abuse 152

3. Putting it Together: Hendricks and the Dangerousness of

Substance Abusers .................................................................. 153

IV. The Problem with Civilly Committing Substance Abusers ............... 154

A. The Fundamental Nature of Liberty .......................................... 155

1. The Failure of the Criminal Act Rationale ........................... 155

2. The Failure of the Parens Patriae or "They Need

Treatment Anyway" Rationale ............................................. 157

3. The Failure of the Police Power Rationale .......................... 158

B. Some Suggestions for Mitigating the Problem .......................... 160

1. Judicial Options ................................................................... 160

a. The U.S. Supreme Court's Options..............................160

b. State Judicial Options................................................161

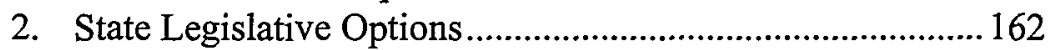

Conclusion 163 


\section{A Population at Risk: Civil Commitment of Substance Abusers After Kansas v. Hendricks}

Mara Lynn Krongard

In its 1997 decision, Kansas v. Hendricks, the U.S. Supreme Court radically changed the face of civil commitment. In finding the Kansas Sexually Violent Predators Act constitutional, the Court liberalized the first constitutional requirement for involuntary commitment from "mental illness" to a much broader "mental abnormality" standard, without correspondingly restricting the second requirement of dangerousness. The decision essentially authorizes states to civilly commit a broad range of individuals without sufficient due process protections. This Comment explores the possibilities for expansion of civil commitment in the wake of Hendricks. It argues that the holding was unjustifiably broad, focusing in particular on the potential danger facing substance abusers. In conclusion, it offers several suggestions for mitigating the potential misuse of this dangerous precedent.

\section{INTRODUCTION}

In its 1997 decision in Kansas v. Hendricks, ${ }^{1}$ the U.S. Supreme Court reopened the civil commitment process to potentially widespread abuse of individual substantive due process rights. ${ }^{2}$ From the 1970 s to the early 1990 s, the Court searched for and eventually found a middle ground between, on the one hand, protecting an individual's liberty interest and due process rights from virtually unimpeded state commitment actions and, on the other hand, preserving a state's parens patriae power to act as guardian of its citizens. ${ }^{3}$ Then, in Hendricks, a sweeping decision based on semantic sleight of hand cloaked as separation of powers, the Court seeiningly returned to the pre-1970s era, when very little evidence was needed to involuntarily confine an individual to a mental institution. In doing so, the Court substantially increased the potential for unwarranted civil commitment.

1. 521 U.S. 346 (1997).

2. Because civil commitment statutes are traditionally within the states' sphere of power, the due process protections limiting them are those guaranteed by the Fourteenth Amendment. All discussions of due process in this Comment thus refer to protections under the Fourteenth Amendment.

3. See infra Part 1.B. 
In Hendricks, the U.S. Supreme Court upheld the Kansas Sexually Violent Predators Act, which established procedures for the civil commitment of mdividuals who, due to a "mental abnormality" or a "personality disorder," are likely to engage in "repeat acts of sexual violence." The Kansas statute is parallel in structure to traditional civil commitment statutes, which also generally require two findings: "mental illness," along with evidence that the individual is likely to pose a danger to himself or others. ${ }^{5}$ Despite its apparent similarity to ordinary civil commitment statutes, however, upon closer scrutiny both elements of the Kansas statute are substantially different.

The first prong of the Kansas statute casts a much wider net than traditional civil commitment statutes. As many commentators in both the legal and mental health professions have noted, a finding of mental abnormality is not equivalent to a finding of mental illness. "Mental abnormalities" comprise a substantially broader range of diagnoses; arguably any individual who sees a psychologist can meet this statutory requirement. ${ }^{7}$

By contrast, the second element of the Kansas statute, which requires that an individual be likely to engage in "repeat acts of sexual violence," is much more specific, and therefore more restrictive than the traditional requirement of evidence of dangerousness. The Kansas statute is targeted at "sexually violent predators," who are deemed likely to engage in future acts of sexual violence because they have previously been convicted of or charged with sexually violent offenses. ${ }^{8}$ These requirements serve to limit confinement to a particularly dangerous population with extremely high rates of recidivism. ${ }^{9}$ Traditional civil commitment statutes, on the other hand, provide no such criminal history requirements, nor do they provide

4. KAN. STAT. ANN. §§ 59-29a01-04. (1994).

5. See Edward Beis, State Involuntary Commitment Statutes, 7 Mental Disability L. ReP. 358 (1983) (reviewing the basic characteristics of involuntary commitment statutes in all fifty states). A series of U.S. Supreme Court cases between 1975 and 1992, discussed infra Part 1.B.2, created and refined the constitutional boundaries of these statutes.

6. See, e.g., Brief of Amicus Curiae, Washington State Psychiatric Association, Kansas v. Hendricks, 521 U.S. 346 (1997) (No. 95-1649) [hereinafter Brief, Washington State Psychiatric Association].

7. See infra Part I1.B (discussing these terms in more detail); see also Brief, Washington State Psychiatric Association, supra note 6.

8. See Kan. Stat, ANN. \$ 59-29a02 (1994).

9. See Jean Peters-Baker, Challenging Traditional Notions of Managing Sex Offenders: Prognosis Is Lifetime Management, 66 UMKC L. REv. 629 (1998) (reviewing the literature on treatment and recidivism of sex offenders and proposing punishment and treatment based on the specific type of sex offender involved). The author cites a variety of findings on the recidivism of sex offenders. "As many as sixty percent of child molesters with two or more arrests were convicted of a sexual crime against a child within twenty years of their first conviction." Id. at 635. Another study found that "of convicted rapists under thirty-six years of age at their release back into society, twentyeight percent recidivated the crime of rape." Id. at 641. In sum, "the notion that sex crimes are isolated behaviors is pitifully inaccurate." Id. at 645 . 
very helpful guidelines as to what is intended by the word "dangerous." 10 Moreover, the predictions of violence used in traditional civil commitment proceedings are famously inaccurate. " Several studies have found that experts attempting to predict dangerousness are wrong more than half the time. ${ }^{12}$

Given the wide range of "abnormalities" that can now fulfill the first statutory requirement, a more restrictive second element seems an appropriate way to adequately restrict those at risk of civil commitment. Indeed, in approving the Kansas statute, the Supreme Court suggested that it was concerned with casting too wide a net: "We have sustained civil commitment statutes when they have coupled proof of dangerousness with the proof of some additional factor, such as a 'mental illness'.... These added statutory requirements serve to limit involuntary civil confinement to those who suffer from a volitional impairment rendering them dangerous beyond their control."13 Despite this language, however, the Supreme Court failed to explicitly hold that the broader "mental abnormality" standard could only be used in conjunction with a more narrowly tailored finding of dangerousness; rather, the Court broadly approved the "mental abnormality" language, requiring only that, like all traditional civil commitment statutes, evidence of a "mental abnormality" be accompanied by some showing of dangerousness.

By failing to limit the new broader standard for mental disorder to statutes which also contain a heightened requirement for dangerousness, the Supreme Court invited the use of civil commitment for individuals who are neither mentally ill nor have a history of victimizing behavior. Before Hendricks, an individual deemed dangerous based on uncertain criteria was protected by the constitutional requirement that he also be found mentally ill; now, because only a finding of mental abnormality is required, nearly anyone deemed potentially dangerous could be committed. Oddly, this is exactly what the Court sought to avoid in the years leading up to Hendricks. ${ }^{14}$

10. See Beis, supra note 5. For example, Connecticut defines "[d]angerous to self or others" as "a substantial risk that physical harm will be inflicted by an individual upon his or her own person or upon another person." Id. at 359 (quoting CONN. GEN. STAT. ANN. $\$ 17-176$ (1982)). Note that there are no guidelines as to how great a risk is "substantial," or how severe "physical harm" must be to warrant commitment. There is also no requirement for a showing of a history of dangerousness, although such evidence would clearly speak to risk for future behavior.

11. See Clinical and Actuarial Predictions of Violence, in MODERN SCIENTIFIC EVIDENCE 287, 308 (David L. Faigman, et al. eds., 1997) [hereinafter Predictions of Violence]; see also infra Part III.C.2.

12. See infra Part III.C.2.a.

13. Hendricks, 521 U.S. at 358.

14. See, e.g., Foucha v. Louisiana, 504 U.S. 71 (1992); see also infra Part 1.B.2. 
Should states choose to enact legislation using the broader "mental abnormality" criteria for general civil commitment statutes, ${ }^{15}$ substance abusers would likely be at considerable risk of commitment, for several reasons. First, this population has been party to several constitutional battles in recent years, and has lost in most cases; considerable evidence demonstrates that courts have been willing to narrowly construe constitutional rights where the "War on Drugs" is concerned. ${ }^{16}$ Second, the idea of using civil commitment for substance users is not novel; during the "crack epidemic" of the 1980s, the Bush Administration investigated the "use of civil commitment by the states, including obstacles to its wider use," with a particular eye toward pregnant, cocaine-abusing women. ${ }^{17}$ Finally, and perhaps most problematic, it would be relatively easy to civilly commit substance abusers under a statutory construction requiring "mental abnormality" and evidence of future dangerousness. Substance abuse disorders appear to fit the description of "mental abnormality"18 and, at least in some cases, courts have found that substance abuse itself can constitute a danger to oneself. ${ }^{19}$ Moreover, according to many violence prediction studies, substance abuse is the single highest risk factor for future violence. ${ }^{20}$

15. To date, several states have adopted sexually violent predator ("SVP") laws imitating the broad language of the Kansas statute. See Lisa Kavanaugh, Massachusetts's Sexually Dangerous Persons Legislation: Can Juries Make a Bad Law Better?, 35 HARV. C.R.-C.L. L. Rev. 509 (2000) (reviewing the Massachusetts SVP statute modeled after Kansas's); In re Young, 857 P.2d 989 (Wash. 1993) (upholding the Washington SVP statute which was the predecessor to Kansas's). However, none have yet applied this broader language to general civil commitment statutes.

16. See infra Part Ill.A.

17. Sandra Anderson Garcia \& Ingo Keilitz, Involuntary Civil Commitment of Drug-Dependent Persons with Special Reference to Pregnant Women, 15 Mental \& Physical Disability L. Rep. 418, 418 (1991) (quoting The White House, National Drug Control Strategy $42-43$ (1989)); see also Laura E. Gomez, Misconceiving Mothers: Legislators, Prosecutors, and the Politics of Prenatal Drug Exposure (1997).

18. See, e.g., American Psychiatric Association, Diagnostic and Statistical Manual of Mental Disorders: DSM-IV (4th ed. 1994) [hereinafter DSM-IV]. The Diagnostic and Statistical Manual of Mental Disorders ("DSM"), a widely used taxonomy of mental disorders, characterizes a substance abuse disorder as "a maladaptive pattern of substance use manifested by recurrent and significant adverse consequences related to the repeated use of substances." Id. at 182. This is distinguished from substance dependence, which also includes a pattern of compulsive use, tolerance, or withdrawal (in common parlance, addiction). Id.

19. See, e.g., In re Marquardt, 427 N.E.2d 411, 413 (111. App. Ct. 1981) (holding that an individual with a history of substance abuse was clearly a danger to himself because of the chance he would take a damaging dose of synthetic heroin); In re Evans, 408 N.E.2d 33, 35 (Ill. App. Ct. 1980) (holding that an individual posed a danger to himself because of his "inability to comprehend the serious harm that could result to him from drinking alcohol while taking phenobarbital").

20. See Jeffrey W. Swanson, Mental Disorder, Substance Abuse, and Community Violence, in Violence and Mental DisoRder: Developments in Risk Assessment (John Monahan \& Henry Steadman eds., 1994) (reviewing a study of the correlation between violence and mental disorder and substance abuse, commonly viewed as two of the best predictors of violence, which found that a dual diaguosis of mental disorder and substance abuse is correlated with the highest probability of violence, but that standing alone substance abusers have a higher probability of future violence than the nonsubstance-abusing mentally disordered). 
Although civil commitment of substance abusers under broad, "mental abnormality" general civil commitment statutes would likely pass constitutional muster after Hendricks, such action would represent a substantial violation of individual substantive due process rights. The Due Process Clause $\mathrm{e}^{21}$ includes "a substantive component that bars certain arbitrary, wrongful government actions 'regardless of the fairness of the procedures used to implement thein." 22 The Hendricks Court responded to Hendricks's due process challenge by pointing out that "an individual's constitutionally protected interest in avoiding physical restraint" is not absolute and "may be overridden even in the civil context" for reasons such as protecting the common good from dangerous individuals. ${ }^{23}$ However, while there may be strong evidence that incapacitating Hendricks (or other sexually violent predators) would protect the public good, the same cannot necessarily be said for substance abusers, especially those predicted to be dangerous based on unreliable violence prediction methods. Restraining such individuals without a substantial showing that restraint is necessary for the public good would clearly violate their right to freedom from deprivation of liberty without due process of law.

Part 1 of this Comment summarizes the development of civil commitment law, from the earliest beginnings to the period between 1970 and 1997, when several U.S. Supreine Court cases contributed to the development of a modern legal frainework for commitinent. Part II examines the Hendricks decision in detail, focusing on its implications for the future of civil commitment practices. Part III explores the decision's potentially dangerous effects on substance abusers. Finally, Part IV summarizes the problems created by Hendricks, stressing in particular the due process implications of civilly committing individuals on grounds of substance abuse alone, and offers some suggestions on how these dangers can be mitigated.

\section{I \\ The Development of Civil Commtment Law}

\section{A. Civil Commitment to 1970}

The earliest civilizations recognized the need for special care for the mentally ill. Ancient Greek philosophers advocated caring for the mentally

21. U.S. CONST. amend. XIV ("No state shall ... deprive any person of life, liberty, or property, without due process of law....").

22. In re Hendricks, 912 P.2d 129, 133 (Kan. 1996) (citation omitted). Hendricks himself raised a substantive due process claim, arguing essentially that the Supreme Court's earlier cases on civil commitment had set clear constitutional boundaries requiring a showing of mental illness, and that the new broader standard deprived him of his liberty without that constitutionally required showing. See id. at $137-38$.

23. 521 U.S. $346,356-57$ (1997). 
ill in "a comfortable, sanitary, well-lighted place,"24 and the Romans appointed guardians of the property owned by the mentally ill. ${ }^{25}$

During the Middle Ages, the concept of parens patriae power developed in English law. ${ }^{26}$ Literally translated as "parent of the country" and originally referring to a monarch, parens patriae describes:

a state government in its role as protector of the people, and especially of children and the mentally infirm. In this role, the state may initiate certain civil actions to protect the interests of the state on behalf of all its people, or to protect people who lack the legal capacity to protect their own interests, as by ... institutionalizing incompetents who pose a danger to themselves or others. ${ }^{27}$

Under parens patriae authority, the King would act as guardian of the property belonging to the mentally ill; the individuals themselves were often committed to the care of friends or family. ${ }^{28}$

The concept of parens patriae eventually made its way to colonial America. By the mid-nineteenth century, several asylums for the housing of violent, mentally ill individuals existed in America. ${ }^{29}$ The procedural safeguards against commitment of individuals were slim, and during the late nineteenth century a reform effort led by individuals "who had been committed on flimsy authority" attempted to construct legal procedures for the commitment process. ${ }^{30}$ However, the reform effort was not successful. Largely because of medical improvements in diagnosing and treating mental illness, along with increasing legislative confldence in these improvements, "[d]uring the first two-thirds of the 20th century, most changes in civil commitment law aimed at making commitment easier rather than more difficult." ${ }^{31}$ By 1970, thirty-one states had statutes, based on the parens patriae rationale, which provided for commitment when one or more physicians certified that an individual was mentally ill and needed treatment. $^{32}$

\section{B. Backlash and the Middle Ground: The 1970s to 1997}

\section{Challenges to the Old Regime}

In the 1970s, civil commitment law drew the attention of the legal profession. The status quo of involuntary commitment of the mentally ill

24. Samuel J. Brakel \& Ronald S. Rock, eds., The Mentally Disabled and the Law 1 (1971).

25. Id.

26. See Gary B. Melton et al., Psychological Evaluations for the Courts: A HaNdBooK for Mental Health Professionals and Lawyers 299 (2d ed. 1998).

27. RANDOM House LEgal DictionaRY 188 (1996).

28. Melton eT AL., supra note 26, at 299-300.

29. Id. at 26.

30. Id. at 299.

31. Id.

32. See id. at 300 . 
based on no more than a need for treatment faced a series of challenges, all of them focused on the notion that civil commitment resulted in a serious deprivation of individual rights. ${ }^{33}$

These attempts at reform began by challenging the underlying rationale of parens patriae. Historically, civil commitment had been viewed as a benevolent act of the state in its capacity as guardian of the mentally infirm. In theory, commitment was in the best interest of the individual because he needed treatment. In practice, however, the state hospitals were "an acknowledged disaster" 34 and did not ensure proper treatment. Moreover, committed individuals suffered a loss of physical freedom that, given the failure of treatment, was practically imdistinguishable from incarceration in prison. In some sense this loss of liberty was even more severe than that suffered by criminal convicts, because individuals who were committed often faced significant curtailment of their rights even after release, such as restrictions on the right to obtain a driver's license, to marry, to enter into contracts, to vote, and to serve on juries. ${ }^{35}$

Having disposed of the myth of the benevolent state, opponents turned to the criteria for civil commitment. With respect to mental illness, there was concern about the subjectivity of the diagnosing physician and the lack of established criteria by which to judge an individual. According to one scholar, addressing this issue in 1968, "the definition of mental illness is left largely to the user and is dependent upon the norms of adjustment that he employs.... [T] he diagnostician has the ability to shoehorn into the mentally diseased class almost any person he wishes, for whatever reason, to put there. ${ }^{" 36}$ Lower courts began to agree that statutory guidelines were necessary to prevent commitment based entirely on subjective opinions of psychiatrists. $^{37}$

In addition, there were few procedural safeguards in place to ensure a complete and fair review of an individual's case before involuntarily committing him. For example, one mdividual in Pennsylvania was civilly committed after a hearing for which he had only one day's notice to prepare. ${ }^{38}$ Further, he was given neither advance warning of the testimony

33. Id.

34. Alan Stone, Mental Health and the Law: A System in Transitron 1 (1975), quoted in MELTON ET AL., supra note 26, at 301.

35. MELTON ET AL., supra note 26, at 302.

36. Joseph M. Livermore et al, On the Justification for Civil Commitment, 117 U. PA. L. REv. $75,80(1968)$.

37. See, e.g., Lessard v. Schmidt, 349 F. Supp. 1078, 1090-93 (E.D. Wis. 1972), vacated by 414 U.S. 73 (1974), on remand 379 F. Supp. 1376 (E.D. Wis. 1974), vacated by 421 U.S. 957 (1975), on remand 413 F. Supp. 1318 (E.D. Wis. 1976). In Lessard, the court criticized the statute making such commitments possible, and declared it unconstitutional for failing to provide constitutional safeguards. See also Commonwealth ex rel. Finken v. Roop, 339 A.2d 764, 773-79 (Pa. Super. Ct. 1975) (overtuming state statute on commitment procedures, finding that it was unconstitutionally vague and provided inadequate procedural due process protections).

38. Finken, 339 A.2d at 769. 
against him nor the opportunity to cross-examine his principal accuser. ${ }^{39}$ Similarly, in Wisconsin, a woman was held for sixteen days before being granted a simple probable cause hearing. ${ }^{40}$ She received only eighteen hours notice and no other information about the hearing. ${ }^{41}$ She remained in custody for twenty-six days before a full hearing with her attorney present, and even then was given no information regarding the testimony against her. ${ }^{42}$

Going a step further, critics pushed for more substantive criteria for civil commitment. The argument for requiring a prediction of dangerousness to self or others was a logical consequence of the rejection of parens patriae. Since the state could no longer justify its actions solely under a theory of benevolence, civil commitment was arguably an exercise of a state's police power ${ }^{43}$ to safeguard the health, safety, and general welfare of people in the state. ${ }^{44}$ Thus, civil commitment came to be viewed much more like criminal incarceration than state charity. And, just as criminal law generally forbids conviction on the basis of mens rea alone (without an overt act), so mental illness alone should not be sufficient to commit an individual. ${ }^{45}$

Many lower courts accepted this view and began to call for state legislatures to incorporate more substantive criteria into civil commitment statutes. States began to develop statutory definitions of mental illness, including terins of severity, thereby reducing the discretion of diaguosing physicians. Michigan's statute is typical. It defines mental illness as a "substantial disorder of thought or mood which significantly impairs judgment, behavior, capacity to recognize reality, or ability to cope with the ordinary demands of life." treatment" in the criteria for civil commitment. ${ }^{47}$ More significantly, all civil commitment statutes eventually required a showing that an individual posed a danger to himself or others. ${ }^{48}$ As the next Part discusses, the U.S.

39. Id. at 770 . The commitment was overturned on appeal. Id. at 779 .

40. Lessard, 349 F. Supp. at 1090-93. This commitment was overturned in a class action suit in federal district court contesting the validity of Wisconsin's civil commitment procedures. $I d$. The judgment of the federal court, although initially vacated, was ultimately reinstated. Lessard v. Schmidt, 413 F. Supp. 1318 (E.D. Wis. 1976).

41. Lessard, 349 F. Supp. at 1090-93.

42. Id.

43. MELTON ET AL., supra note 26, at 303.

44. Random House Legal DictionaRy 196-97 (1996) (defining "police power").

45. MELTON ET AL., supra note 26, at 303.

46. Mich. Stat. AnN. $\S 14.800(400(a))$. For excerpts from other states' criteria, see Beis, supra note 5 .

47. See John Parry, Involuntary Civil Commitment in the 90s: A Constitutional Perspective, 18 Mental \& Physical Disability L. ReP. 320, 330-36 (1994) (listing thirty-two states requiring the need for treatment).

48. See id. at 323 . 
Supreme Court demonstrated support for these reforms, albeit in a somewhat reserved fashion.

\section{The Development of Modern Civil Commitment Law: 1970s to Pre- Hendricks}

As a result of reform efforts in the 1970s, the U.S. Supreme Court accepted the need for additional statutory requirenents for civil commitment, such as the need for treatment or evidence of dangerousness, to protect the liberty interests of the mentally ill. However, the Court was not willing to treat civil commitment as completely analogous to criminal commitment. In a series of important cases, the Court set about structuring and maintaining a civil commitment jurisprudence that was more respectful of individual rights than the pre-1970s regime, yet less rigorous with respect to constitutional standards than the criminal system. In short, the Court found a middle ground.

a. The Middle Ground: O'Connor v. Donaldson and Youngberg v. Romeo

In the 1975 decision of $O^{\prime}$ Connor v. Donaldson, the U.S. Supreme Court appeared to agree with reformers that mental illness alone was insufficient to warrant confinement. ${ }^{49}$ Donaldson brought suit against the superintendent and staff members of a state mental hospital, alleging that he had been committed involuntarily in violation of his constitutional right to liberty. ${ }^{50}$ Donaldson argued, and the jury agreed, that he had received no treatment for his supposed illness during his confinement..$^{51}$ No claim was ever made that Donaldson posed a danger to himself or others. ${ }^{52}$ The Supreme Court held that such involuntary commitment, at least without provision of treatment, was unconstitutional:

A finding of "mental illness" alone cannot justify a State's locking a person up against his will and keeping him indefinitely in simple custodial confinement. Assuming that that term can be given a reasonably precise content and that the "mentally ill" can be identified with reasonable accuracy, there is still no constitutional basis for confining such persons involuntarily if they are dangerous to no one....53

By leaving open the question of "whether the State may compulsorily confine a non-dangerous, mentally ill individual for the purpose of treatment," $" 54$ the majority opinion implied the Court's unwillingness to

\footnotetext{
49. 422 U.S. $563,575(1975)$.

50. Id. at 565 .

51. Id. at 569,572 .

52. Id. at 568 .

53. Id. at 575 .

54. Id. at 573 .
} 
completely replace the parens patriae rationale with a police power justification for civil commitment; to do so would be to equate civil commitment with criminal incarceration. In a lengthy concurrence, Chief Justice Burger explicitly demonstrated the Court's preference to limit the outer boundaries of parens patriae rather than completely abandon the concept, explaining that "the States are vested with the historic parens patriae power," but that power is subject to due process limitations. ${ }^{55}$

In 1982, the Court revisited this question in Youngberg v. Romeo, a case that considered the rights of a mentally-retarded individual confined in a state institution..$^{56}$ Romeo's mother filed suit on his behalf, alleging that the hospital was violating his constitutional rights to liberty under the Fourteenth Amendment by not providing him with training or "habilitation" that would enable him to avoid or limit the restraints placed upon him. ${ }^{57}$ The Court agreed that "there is a constitutionally protected liberty interest in safety and freedom from restraint," and that "training may be necessary to avoid unconstitutional infringement of those rights." 58 Although the Court again took care to limit its holding to the facts and avoided announcing a constitutional right to treatment or habilitation, three concurring justices commented that under different facts they would consider an argument for the existence of such a requirement. ${ }^{59}$ Taken together, Donaldson and Youngberg establish a right against civil commitment absent strong justification and strongly suggest that there may be a right to obtain treatment minimally necessary to prevent or reduce commitment. ${ }^{60}$ In other words, the Court found a middle ground: while stopping short of constitutionally requiring states to provide treatment to committed individuals, the Court opined that such treatment was at least preferable, and potentially necessary.

\section{b. Addington v. Texas}

The search for a middle ground was even more evident in the Court's resolution of another major civil commitment case, Addington v. Texas. ${ }^{61}$ The question before the Court was what standard of proof courts should use in determining whether the statutory requirements for civil commitment had been met. Appellant Addington conceded that he suffered from a mental illness, but argued "that there was no substantial basis for concluding that he was probably dangerous to himself or others." ${ }^{262}$ The

55. Id. at 583 (Burger, J., concurring).

56. 457 U.S. 307 (1982).

57. Id. at 307,318 .

58. Id. at 318 .

59. Id. at 329.

60. See Parry, supra note 47 , at 323.

61. 441 U.S. 418 (1979).

62. Id. at 421 . 
charge of dangerousness was based on the state's evidence that "he had been involved in several assaultive episodes while hospitalized and that he had caused substantial property damage both at his own apartment and at his parents' home." ${ }^{\prime 33}$ Addington essentially contended that, because he stood to lose his liberty much like a criminal convict, the state should have to demonstrate that he was dangerous beyond a reasonable doubt; anything less would violate his procedural due process rights. ${ }^{64}$

On appeal, the Texas Supreine Court held that a "preponderance of the evidence" standard was sufficient to satisfy due process concerns for several reasons, all of which had been discussed in an earlier Texas case. ${ }^{65}$ The court was concerned that the state would not be able to meet the more rigorous standard in predicting that an individual would definitely be dangerous in the future. ${ }^{66}$ Additionally, it distinguished between criminal and civil commitment on the ground that Texas law required treatment for the latter, as well as periodic review and release upon a showing that the individual was no longer dangerous. ${ }^{67}$

The U.S. Supreme Court reversed. ${ }^{68}$ In a unamimous opinion, the Court explored the continuum of standards of proof and the types of cases with which they are traditionally associated. The Court explained that in typical civil suits, which are usually disputes between private parties, the plaintiffs are held only to a "preponderance of the evidence" standard of proof because "society has a mimimal concern with the outcoine of such private suits" and under the preponderance standard the litigants share the risk of error. ${ }^{69}$ These civil cases are to be juxtaposed with criminal cases, which require the "beyond a reasonable doubt" standard because "the interests of the defendant are of such inagnitude that historically and without any explicit constitutional requirement they have been protected by standards of proof designed to exclude as nearly as possible the likelihood of an erroneous judgment."

The Court agreed with Addington that civil commitinent is not an ordinary civil proceeding, noting that "civil commitment for any purpose constitutes a significant deprivation of liberty that requires due process protection," commitment proceeding is of such weight and gravity that due process

63. Id. at $420-21$.

64. Id. at $422-23$.

65. Id. at 422 (discussing State v. Turner, 556 S.W.2d 563 (Tex. 1977), cert. denied, 435 U.S. 929 (1978)).

66. Id.

67. Id. The court also noted that Texas rules of procedure only allowed jury instructions requiring "beyond a reasonable doubt" or "preponderance of the evidence" standards. Id.

68. Id. at 433 .

69. Id. at 423 .

70. Id.

71. Id. at 425 . 
requires the state to justify confinement by proof more substantial than a mere preponderance of the evidence." 72 However, the Court stressed that civil commitment takes place pursuant to both parens patriae authority and police power, ${ }^{73}$ once again distinguishing civil commitment from criminal incarceration. The Court also expressed concern that a reasonable doubt standard would be difficult to meet, ${ }^{74}$ and that the inability to achieve cominitment under such standards could harm the legitimate interests of the state in protecting its citizens and treating its mentally ill. ${ }^{75}$ Shying away from the strict criminal standard, the Court found that "[d]ue process does not require that every conceivable step be taken, at whatever cost, to eliminate the possibility of convicting an innocent person." 76 The Court ultimately settled on the true middle ground, requiring that civil commitment standards proceed under at least a "clear and convincing evidence" standard of proof. ${ }^{77}$

\section{c. Shoring Up the Middle Ground: Foucha v. Louisiana}

Having established a middle ground between, on the one hand, protecting an individual's liberty interest and due process rights from virtually unimpeded state commitment actions and, on the other hand, preserving a state's parens patriae power to look after its citizens, the Supreme Court reinforced its position in Foucha v. Louisiana, ${ }^{78}$ in which it disallowed an attempt to broaden statutory constraints on who may be confined involuntarily. Foucha addressed the possibility of widening the first prong of the civil commitment test to include individuals that have mental disorders that are not mental illnesses. Mental disorder is a broad term used to describe any "clinically significant behavior or psychological syndrome that is associated with present distress, disability, suffering, or loss of freedom."" Not all mental disorders are mental illnesses. Diagnosing a mental illness requires the additional step of assessing the incapacitating effect of the disorder: "In the context of involuntary commitment, it is widely understood in the psychiatric profession that to be identified as 'mentally ill,' a person must be suffering from a serious cognitive, perceptual or affective dysfunction which significantly impairs that person's ability to function in

72. Id. at 427 .

73. Id. at 426 .

74. Id. at 429 ("Given the lack of certainty and the fallibility of psychiatric diagnosis, there is a serious question as to whether a state could ever prove beyond a reasonable doubt that an individual is both mentally ill and likely to be dangerous.").

75. Id. at 430 .

76. Id. (citation omitted).

77. Id. at 433.

78. 504 U.S. 71 (1992).

79. DSM-IV, supra note 18 , at xxiv. These can include mild depression, nicotine addiction, or virtually any "distressing" condition. See Brief, Washington State Psychiatric Association, supra note 6. 
ordinary life. ${ }^{180}$ In short, while all mental illnesses are mental disorders, many mental disorders are not mental ilhiesses.

In Foucha, the appellant was tried for aggravated burglary and discharge of a firearm, but was found not guilty by reason of insanity. Following this type of acquittal, a defendant is generally automatically committed for evaluation for thirty to sixty days. At the end of this time a court must decide if the individual meets the criteria for civil commitment-that is, whether he is mentally ill and dangerous. If committed, the individual remains confined until he or a doctor shows, at a release hearing, that he is no longer mentally ill. ${ }^{81}$ Louisiana law follows this general rule; after his acquittal, Foucha was committed "until such time as doctors recommend that he be released, and until further order of the court."

At Foucha's hearing, a court-appointed doctor testified that he showed no signs of mental illness, explaining that at the time of commitment Foucha had probably suffered from a temporary drug-induced psychosis. ${ }^{83}$ He was not given a completely clean bill of health, however; two other doctors reported that Foucha had "an antisocial personality, a condition that is not a mental disease and that is untreatable." ${ }^{.4}$ Given this diagnosis, the three-member panel reviewing Foucha's case recommended that he be discharged..$^{85}$ Notwithstanding the evidence that Foucha was not mentally ill and that his antisocial personality disorder was not treatable, the trial court refused to release him, on grounds that he was dangerous to himself and others. ${ }^{86}$ In doing so, they rejected Foucha's argument that his continued commitment violated his due process rights by permitting confinement based on dangerousness alone. ${ }^{87}$

In evaluating Foucha's due process claim, the Louisiana Supreme Court relied on a passage from an earlier U.S. Supreme Court decision, Jones v. United States. ${ }^{88}$ Jones, which addressed commitment proceedings for insanity acquittees, cited with apparent approval a District of Columbia statute that entitled an acquittee, within fifty days of commitment, "to a judicial hearing to determine his eligibility for release, at which he has the burden of proving by a preponderance of the evidence that he is no longer mentally ill or dangerous. ${ }^{89}$ Since there was evidence that Foucha was still

\footnotetext{
80. Brief, Washington State Psychiatric Association, supra note 6.

81. Melton Et AL., supra note 26, at 332-33.

82. 504 U.S. at 74.

83. Id. at 75 .

84. Id.

85. Id. at 74 .

86. Id. at 75 .

87. Id.

88. 463 U.S. 354 (1983).

89. Id. at 357 (emphasis added).
} 
dangerous, the state supreme court ordered that he be returned to a mental institution. ${ }^{90}$

The U.S. Supreme Court reversed the lower court's order to continue Foucha's commitment, citing several earlier decisions. First, in response to the passage from Jones relied upon by the lower court, the Court pointed to another passage from the case stating that " $[t]$ he committed acquittee is entitled to release when he has recovered his sanity or is no longer dangerous." the majority in Foucha followed suit, explicitly stating its reliance on Donaldson for the idea that "the acquittee may be held as long as he is both mentally ill and dangerous, but no longer.... [Donaldson] held as a matter of due process that it was unconstitutional for a State to continue to confine a harmless, mentally ill person." ${ }^{\text {92 }}$ Finally, the Court repeated Addington's holding that "the State is required by the Due Process Clause to prove by clear and convincing evidence the two statutory preconditions to commitment: that the person sought to be committed is mentally ill and that he requires hospitalization for his own welfare and protection of others." ${ }^{.93}$

Thus, in Foucha the Supreme Court fended off a state's attempt to broaden the boundaries of civil commitment by confining individuals who were not mentally ill. In doing so, it held firm on the due process limitations it had established in Donaldson and Addington. The Court recognized that allowing confinement of insanity acquittees who were not mentally ill was "only a step away from substituting confinements for dangerousness for our present system which, ... aside from permissible confinements for mental illness, incarcerates only those who are proved beyond reasonable doubt to have violated a criminal law. 994

90. 504 U.S. at 75.

91. Id. at 77 (quoting Jones, 463 U.S. at 368 (emphasis added)). Although beyond the scope of this Comment, the clearly contradictory language used in the Jones opinion, as evidenced by the similar but critically different passages cited by the plurality and the dissent (and lower court), is worth noting. Because this issue was only peripherally related to the legal question in Jones, which addressed whether an insanity acquittee could be confined for longer than the maximum possible sentence for the offense from which he was acquitted, the contradiction was never explicitly resolved.

92. 504 U.S. at 77.

93. Id. at 75 .

94. Id. at 83. Although Foucha was a narrowly decided case with only a plurality opinion, the dissent explicitly affirmed the majority's readings of Donaldson and Addington; their contention was that, like Jones, Foucha started from a criminal act and acquittal, and thus the appellant was not necessarily entitled to the extent of due process limits placed on standard commitment proceedings. See $i d$. at 90-95 (Kennedy, J., dissenting) ("In Jones we distinguished criminal from civil commitment, holding that the Due Process Clause permits automatic incarceration after a criminal adjudication and without further process."). 


\section{d. Following Suit: In re Hendricks}

In what seemed like a fairly clear-cut case, the Supreme Court of Kansas followed U.S. Supreme Court precedent on the constitutionality of civil commitment proceedings when it invalidated the 1994 Kansas Sexually Violent Predator Act ${ }^{95}$ for violating Hendricks's substantive due process rights. ${ }^{96}$ Hendricks had served time for multiple counts of "indecent liberties with a child," and was a diagnosed and self-proclaimed pedophile who was likely to continue molesting children ${ }^{97} \mathrm{He}$ was exactly the type of individual the Act sought to commit, and he was the new law's first victim..$^{98}$

Kansas, like most states, had a general civil commitnent statute allowing for involuntary commitment of mentally ill individuals who pose a danger to themselves or others. ${ }^{99}$ As in many states, perhaps in light of Donaldson and Youngberg, the statute required individuals to be in need of treatment in order to be classified as mentally ill. ${ }^{100}$ However, it is commonly recognized that the ability of mental health professionals to treat pedophilia is questionable at best. ${ }^{101}$ This fact was recognized by the Kansas legislature, and was one of the primary reasons for the development of a specific statute targeted at offenders like Hendricks: "In contrast to persons appropriate for civil commitment under [Kansas's general civil commitment statute], sexually violent predators generally have antisocial personality features which are unamenable to existing mental illness treatment modalities...."102 Thus, the legislature wrote its sexually violent predator ("SVP") statute to provide a legal mechanism for the commitment of those with a "personality disorder" or "mental abnormality" who meet specific dangerousness criteria. ${ }^{103}$

In In re Hendricks, the Kansas Supreme Court began its evaluation of the new statute by interpreting the Due Process Clause of the Fourteenth Amendment to "contain[] a substantive component that bars certain arbitrary, wrongful government actions 'regardless of the fairness of the

95. KAN. StaT. ANN. $\$ 59-29$ a01 et seq. (1994).

96. In re Hendricks, 912 P.2d 129, 138 (Kan. 1996).

97. Id. at 130.

98. See Kansas v. Hendricks, 521 U.S. 346, 350 (1997).

99. KAN. STAT. ANN. \$59-2901 et seq. (1994).

100. Id.

101. See generally, Samuel Jan Brakel \& James L. Cavanaugh, Jr., Of Psychopaths and Pendulums: Legal and Psychiatric Treatment of Sex Offenders in the United States, 30 N.M. L. REv. 69 (2000); see also Jean Peters-Baker, supra note 9, at 634 ("A 'true pedophile' has been held incapable of treatment since the offender's 'personality structure' inherently leads him to commit sexual crimes agaimst children.").

102. In re Hendricks, 912 P.2d 129, 131-32 (Kan. 1996).

103. "'Sexually violent predator' means any person who has been convicted of or charged with a sexually violent offense and who suffers from a mental abnormality or personality disorder which makes the person likely to engage in the predatory acts of sexual violence." KAN. STAT. ANN. $\S 59-29 \mathrm{a} 02$ (a) (1994). 
procedures used to implement them." 104 In this case, Hendricks's claimed the statute's "mental abnormality" requirement did not meet the constitutional standard of mental illness established in Foucha, and that therefore his confinement violated his substantive due process rights. ${ }^{105}$

As in Foucha, the Kansas Supreme Court first cited Addington for the premise that there are two statutory preconditions to commitment that must be proven by clear and convincing evidence: mental illness and dangerousness to oneself or others. ${ }^{106}$ The court next pointed to the Supreme Court's conclusion in Foucha that appellant's potential dangerousness, which stemmed from his antisocial personality, was not enough to defeat his "liberty interest in being freed from indefinite confinement in a mental facility."107

The court's next task was to determine whether "mental abnormality" was more analogous to the "mental illness" required by Addington or the "antisocial personality" found insufficient for confinement in Foucha. To do so, the Court turned to the Washington Supreme Court's evaluation of Washington's SVP statute, on which the Kansas statute was based.

In In re Young, the Washington Supreme Court rejected a substantive due process challenge to its SVP statute. The plaintiff in that case suffered from antisocial personality disorder. ${ }^{108}$ The Washington court distinguished Foucha by noting that Foucha had an "antisocial personality," a condition listed in the American Psychiatric Association's Diagnostic and Statistical Manual of Mental Disorders ("DSM") as "a condition not attributable to a mental disorder." 109 In contrast, the court noted, Young suffered from an "antisocial personality disorder," which is a recognized mental disorder according to the DSM. ${ }^{110}$ The Washington court stated that "mental illness"

\footnotetext{
104. 912 P.2d at 133 (citation omitted).

105. Id.

106. Id.; see also supra Part I.B.2.

107. 912 P.2d at 134 .

108. 857 P.2d 989 (Wash. 1993).
}

109. Id. at 1007 n.12 (quoting American Psychiatric Association, Diagnostic AND Statistical Manual of MENTAL Disorders: DSM-III-R 342 (3d rev. ed. 1987) [hereinafter DSM-III-R]). The Washington court used the earlier, revised third edition of the DSM from 1987, abbreviated here as DSM-III-R. The current fourth edition ("DSM-1V") has no changes relevant to this comment. The DSM is a well-known taxonomy cataloging the entire spectrum of mental disorders, as well as a limited number of "conditions not attributable to a mental disorder." One of the chief uses of the DSM is for insurance coverage; many insurance companies will not cover psychiatric or psychological treatment unless the individual is diagnosed under a DSM category. See RALPH REISNER et al., Law and the Mental Health System: Civil and Criminal aspects 15 (3d ed. 1999). The DSM includes a broad range of disorders, from sleepwalking disorder and premature ejaculation to schizophrenia and bipolar disorder. The vast majority of conditions listed are considered to bc mental disorders. However, the DSM does not categorize disorders according to their severity; rather, it groups them by type, such as "anxiety disorders," "adjustment disorders," and "psychosexual disorders." See DSM-IV, supra note 18. The problem with using the DSM as a benchmark for civil commitment is discussed in more detail, infra Part ll.B.

110. 857 P.2d at 1007 n.12 (quoting DSM-III-R 342 (emphasis added)). 
and "mental disorder" are largely synonymous;" thus Foucha forbade the commitment of mdividuals who do not have a mental illness or mental disorder. As for "mental abnormality," while admitting that the term was a legislative construction and not defined in the DSM, the court abided by expert testimony that "mental abnormality" was nearly identical to the notion of 'mental disorder' as defined in the DSM-III-R.".112

The Kansas court in In re Hendricks strongly contested the Washington court's determination that "mental abnormality," "mental illness," and "mental disorder" are essentially synonymous. ${ }^{113}$ The court cited the testimony of Hendricks's doctor to the effect that "mental abnormality" is "a phrase used by clinicians to discuss abnormality or deviance, but ... is not defined in [the DSM and] [i]t therefore could not be used appropriately in a formal diagnosis."114 The court also found fault with its peers' use of the DSM:

At the heart of the court's reasoning is a selective and inconsistent use of the ... [DSM]. On the one hand, the court rcasons that because "anti-social personality disorder" is defined in the DSM-III-R, it is a mental disorder, and on the other hand, that "mental abnormality" is a mental disorder, notwithstanding that it is not defined as such in the DSM-III-R. Simply stated, mental illness means whatever the Washington court says it means; it is this reasoning which was the basis for the court's conclusion that the Washington act did not conflict with Foucha. ${ }^{115}$

The Kansas court thus explicitly rejected the Young court's reasoming, finding that the statutory requirement of mental abnormality is not equivalent to the constitutional standard of mental illness ${ }^{116}$ and that a commitment based on mental abnormality would violate Hendricks's substantive due process rights. The court repeated the warning of Young's dissenters that "by authorizing the indefinite confinement in mental facilities of persons who are not mentally ill, the Statute threatens not only the liberty of certain sex offenders, but the liberty of us all."117

111. Id. at 1001 n.3 (citing Longman Dictionary of Psychology and Psychiatry 451 (1984)).

112. Id. at 1001 .

113. 912 P.2d at 135 .

114. Id. at 137-38.

115. Id. at 135 (citations omitted).

116. Id. at 137.

117. Id. at 136 (quoting 857 P.2d at 1019). 
II

The Doctrinal About-Face in Civil Commitment Law: Kansas $v$. Hendricks

\section{A. The Decision}

In Kansas $v$. Hendricks, ${ }^{118}$ an opinion marked by a disregard for precedent as well as a dose of intellectual dishonesty, the U.S. Supreme Court reversed the Kansas Supreme Court's decision, finding that the Kansas statute satisfied substantive due process requirements. The statute was clearly based on a need to confine sex offenders, a population concededly not amenable to treatment. Thus, by upholding it, the Court implicitly expressed its willingness to abandon the justification of parens patriae in favor of a police power rationale for civil commitment. More importantly, this paradigm shift was not accompanied by a parallel shift toward the more stringent due process protections provided in criminal processes, even though civil commitment for the purpose of protecting the public bears a stronger resemblance to criminal incarceration than to commitment for the benefit of the committed. Unfortunately, in confining a degenerate, the Court created a dangerous precedent.

Justice Thomas, writing for the majority, began by reviewing the Court's earlier cases on civil commitment. However, his interpretation of the most important cases was cursory at best, and argnably missed the heart of those decisions. For example, while he reiterated Foucha's holding that dangerousness alone is an insufficient basis on which to involuntarily confine an individual, ${ }^{119}$ he failed to explain why sex offenders targeted by the Kansas Act should be treated differently from Foucha. Foucha, who also suffered from an untreatable mental condition that did not technically qualify as a mental disorder, was released on the grounds that his antisocial personality condition was an insufficient basis on which to deprive him of his liberty. ${ }^{120}$ In a similarly ambiguous representation, Justice Thomas cited Addington for the broad proposition that "we have consistently upheld such involuntary commitment statutes provided the confinement takes place pursuant to proper procedures and evidentiary standards." ${ }^{.21} \mathrm{He}$ failed to mention that the statutory requirements for which the Court required a heightened standard of proof in that case included "mental illness." 122

After his intellectually dishonest discussion of these two precedents, Justice Thomas turned to the Kansas statute, focusing on the term "mental

118. 521 U.S. 346 (1997).

119. Id. at 358 .

120. See Foucha v. Louisiana, 504 U.S. 71, $82-83$ (1992). In fairness to Justice Thomas, he has at least been consistent; his Hendricks opinion strongly reflected his dissenting opinion in Foucha. See id. at 102 (Thomas, J., dissenting).

121. Hendricks, 521 U.S. at 357.

122. See Addington v. Texas, 441 U.S. 418 (1979). 
abnormality," which was the basis of Hendricks's substantive due process claim. Although both Addington and Foucha, the two leading precedents, used the term "mental illness," Justice Thomas insisted that the term was "devoid of any talismanic significance." $123 \mathrm{He}$ then listed a variety of terms the Court had used in three previous cases to describe the "mental condition of those properly subject to confinement," 124 including "emotionally disturbed," "mentally ill," "incompetency," and "insanity."125 Here again, Justice Thomas's analysis was not entirely forthright. Two of the cases he cited were Foucha and Addington; although various terms were mentioned throughout those cases, both decisions clearly rested on the term "mental illness." 126 The third case, Jackson v. Indiana, involved pretrial commitment of an individual accused of a crime. ${ }^{127}$ Because the confinement in that case was part of the criminal process, it is inapposite to the case of civil commitment, where an individual faces potentially indefinite confinement completely outside of and without the guarantees of the criminal process. ${ }^{128}$

Having created a fiction whereby all terms referring to mental conditions are indistinguishable, Justice Thomas disposed of the substantive due process claim with a separation of powers argument: "[W]e have never required state legislatures to adopt any particular nomenclature in drafting civil commitment statutes. Rather, we have traditionally left to legislators the task of defining terms of a medical nature that have legal significance."129

Interestingly, not even the state of Kansas had attempted to argue that the issue was one of semantics. The Kansas legislature itself recognized the distinction between mental ilhiess (as defined by the legislature in the general civil commitinent statute) and mental abnormality, and acknowledged that the new statute was broader than the traditional characterization of mental illness. According to its preamble, the specific purpose of the SVP statute was to expand statutory boundaries in order to capture sexually violent predators "who do not have a mental disease or defect that renders them appropriate for imvoluntary treatınent... [but who] have anti-social personality features which are unamenable to existing mental ilhiess treatment modalities...."130 The state argued that its authority to enact the statute stemmed from its police power to detain individuals who, due to

123. 521 U.S. at 359 .

124. Id.

125. Id. (citing Addington, 441 U.S. at 425-26; Jackson v. Indiana, 406 U.S. 715, 732, 737 (1972); Foucha, 504 U.S. at 88).

126. See supra Part I.B.2.

127. 406 U.S. 715 (1972).

128. For instance, the criminal process requires the highest standard of proof, "beyond a reasonable doubt."

129. 521 U.S. at 359.

130. Preamble, Kan. Stat. AnN. § 59-29a01 (1994). 
mental conditions, "pose a danger to public health and safety." ${ }^{131}$ In other words, unlike Justice Thomas, the state openly acknowledged that its statute represented much more than a new word choice, which is certainly within a legislature's prerogative and not subject to judicial interference. Rather, the new law significantly expanded the state's power to override an individual's liberty interest.

Once Justice Thomas transformed the issue from a question of whether the new statute's target population fulfilled Foucha's constitutionally required "mental illness" standard to a matter of synonym choices, the state's position (if not its argument) was easily supported. Although Hendricks's contention had always been that due process required no less than "mental illness," on Justice Thomas's rationale any mental condition appeared sufficient.

Although Thomas refused to narrow the breadth of "mental abnormality," he did attempt to placate would-be critics by implying that Hendricks would have also fit into a more restricted category, such as one requiring a "serious mental disorder." According to Thomas, "[t]he mental health professionals who evaluated Hendricks diagnosed him as suffering from pedophilia, a condition the psychiatric profession itself classifies as a serious mental disorder." $132 \mathrm{He}$ cited the DSM for this proposition. ${ }^{133}$ Once again, Thomas was not completely forthright. The DSM does not classify disorders as "serious." 134 "Seriousness" is neither a technical term nor a term of art in the DSM; its use is purely common langnage. ${ }^{135}$ Thomas's use of the term "serious" seems to imply a judgment about how the disorder affects the individual. However, the DSM explicitly refrains from classifying in this way. It classifies disorders from which people suffer, and makes no assumption that "all individuals described as having the same mental disorder are alike in all important ways." 136 In fact, the DSM "expressly rejects the assertion that a diagnosis of a mental disorder has any bearing upon a person's ability to control themselves." 137 In attempting to use specific facts to justify a broad holding, Justice Thomas implicitly

131. 521 U.S. at 357.

132. Id. at 360 .

133. Id. Thomas also cited two other sources; however, the DSM was the primary citation, and is the most common manual for mental health diagnoses. See RALPH REISNER ET AL., supra note 109, at 15.

134. See DSM-IV, supra note 18.

135. E-mail from Howard Goldman, M.D., PhD, Professor of Psychiatry, University of Maryland School of Medicine, to author (Nov. 28, 2000, 19:07 PST) (on file with author) (explaining, in response to a question, that mental health professionals do not use the term "serious" as a technical term).

136. REISNER ET. AL., supra note 109, at 16. For example, as part of its effort to avoid classifying people, the DSM does not refer to individuals as "schizophrenics," but uses the more cumbcrsome "an individual with Schizophrenia." Id.

137. Rebecca Kesler, Running in Circles: Defining Mental Illness and Dangerousness in the Wake of Kansas v. Hendricks, 44 WAYNE L. REv. 1871, 1893 (1999) (internal citations omitted). 
suggested an unworkable limitation and again demonstrated the failure of the Court to comprehend the nuances of mental disorder taxonomy.

In short, using a series of vague interpretations of precedent and semantic trickery, Justice Thoinas transformed a case about substantive due process limitations on a state's power to override an individual's liberty into a discussion about state legislatures' power to define its own terms. In doing so, Justice Thoinas established a broad holding with no sensible limitations. This holding creates dangerous implications for potential future application.

\section{B. The Implications: An Open Invitation to Expand States' Civil Commitment Power}

Hendricks may be a good representation of the old adage that "bad facts make bad law." No one would seriously dispute that Mr. Hendricks made a compelling case for confineinent. As one commentator noted:

Legal technicalities, by the way, were all Hendricks had to go on, for when it came to the equities or the social interest he, like so many otlier offenders whose names grace our landmark cases, did not have much of a case for release: he had a long history of molesting children, including lis own stepdaughter and stepson .... ${ }^{138}$

Nonetheless, the way in which the U.S. Supreme Court chose to sanction Hendricks's confinement has dangerous implications for future legislative and common law development.

The flaw in Justice Thoinas's opinion was not that it sought to confine Hendricks, a pedophile, but that it failed to distinguish Hendricks's condition from the vast number of other mental abnormalities that should not be considered a sufficient basis for confinement. Justice Thomas could have explicitly distinguished Foucha, in wlich the Court refused to sanction conflnement of a dangerous individual with an "antisocial personality." By explaining why a pedophile is confinable but an individual suffering from an antisocial personality is not, he might have provided more stringent guidelines for legislatures to use im drafting civil commitment statutes. More importantly, in doing so he would have limited the expansion of the Foucha "mental illness" standard, thereby capturing only specific populations known to be particularly dangerous, rather than anyone witl a mental abnormality.

Similarly, Justice Thomas might have sanctioned the broader "mental abnormality" standard only in conjunction with heightened standards for dangerousness, such as those targeting individuals with past convictions for violent or predatory crimes. Alternatively, he could have narrowly

138. Brakel \& Cavanaugh, supra note 101 , at 85 . 
sanctioned the Kansas statute on grounds similar to those in Justice Kennedy's Foucha dissent, emphasizing that because Hendricks's civil commitment stemmed from a criminal action he was not entitled to the same due process protections as non-criminal subjects of commitment proceedings. ${ }^{139} \mathrm{Or}$, he could have rejected the statute altogether while pointing out that the state had foreclosed several alternative options for confining Hendricks, ${ }^{140}$ thereby implying that the state should make use of other options for confinement of individuals like Hendricks. Any of these options would have been legally feasible, as no precedent directly governed the use of a "mental abnormality" standard.

Rather than pursue any of these more limited options, Justice Thoinas authored a sweeping opinion stating that legislatures may adopt and define any nomenclature they choose for the mental state required for civil commitment, ${ }^{141}$ including "mental abnormality," so long as it is accompanied by some showing of dangerousness. ${ }^{142}$ Justice Thomas did not even seek to refine the term "mental abnormality" to exclude certain types of disorders; ${ }^{143}$ he simply suggested that inclusion in the DSM is sufficient. ${ }^{144}$

The DSM, however, is not an appropriate benchmark for mental conditions sufficient to justify confinement in conjunction with evidence of dangerousness. The DSM, the industry standard and a self-proclaimed manual of mental disorders, contains countless diagnosable conditions that a legislature would not likely seek to include in a definition of mental illness. For example, the DSM includes Female Orgasmic Disorder, Caffeine Induced Sleep Disorder, Nightmare Disorder, and Nicotine Use Disorder, to name a few. ${ }^{145}$ The DSM itself cautions that, "[i]t is to be understood that inclusion here, for clinical and research purposes ... does not imply

139. See Foucha v. Louisiana, 504 U.S. 71, 90-95 (1992) (Kennedy, J., dissenting). "In Jones we distinguished criminal from civil commitment, holding that the Due Process Clause permits automatic incarceration after a criminal adjudication and without further process." Id. at 95.

140. As the Kansas Supreme Court noted, the record indicated that Hendricks had at least three felony convictions prior to the conviction of two counts of indecent liberties from which he was about to be released (his imminent release triggered the civil commitment proceedings). However, the State declined to triple his sentence under the Habitual Criminal Act; it also chose to have his sentences for both counts run concurrently, rather than consecutively. Moreover, Hendricks had received the minimum sentence. In other words, the State had multiple options for confining Hendricks for a long time on criminal charges, but instead chose to enter a plea bargain. In re Hendricks, 912 P.2d 129, 13637 (Kan. 1996).

141. 521 U.S. at 359.

142. Id. at 358. Many experts both before and after this decision have stressed that the terms "mental abnormality" and "mental illness" are not synonymous. See, e.g., Brief of Amicus Curiae, National Mental Health Association, Kansas v. Hendricks, 521 U.S. 346 (1997) (No. 5-1649); Brief, Washington State Psychiatric Association, supra note 6.

143. Many states explicitly exclude certain conditions from their definitions of mental illness, such as mental retardation, epilepsy, and developmental disabilities. See Parry, supra note 47, at 323.

144. See 521 U.S. at 360.

145. Brief, Washington State Psychiatric Association, supra note 6 (citing DSM-IV, supra note 18 , at $505,604,580,243$ ). 
that the condition meets legal or other non-medical criteria for what constitutes mental disease, mental disorder, or mental disability."146 The manual's purpose is to achieve a "uniform nomenclature in psychiatry to facilitate statistic-gathering and infornation exchange."147 A professor of law and mental health explained the wide range of disorders as follows:

People consult mental health professionals for an almost endless variety of problems, such as an addiction to sinoking or marital strife. The professionals involved have a number of reasons for inventing labels for these problems.... The fact that the Diagnostic and Statistical Manual (DSM-III) labels these problems "disorders" should [not] ... mislead us to believe that the problems are traditional illness .... In other words, we should not think that a condition is an "illness" just because psychiatrists attempt to treat the condition. ${ }^{148}$

By making "mental abnormality," as defined by inclusion in the DSM, into a constitutionally acceptable standard, even in conjunction with the fairly vague standard for showing dangerousness that is used in non-SVP civil commitinent statutes, the Hendricks decision created a slippery slope. It essentially legalized the civil commitinent of a vast number of people who are neither mentally ill nor have a history of victimizing behavior. As one author noted:

[T]he predator commitment law has detached involuntary commitinent from the medical model of mental illness and bona fide treatment. Once detached, literally no stopping point exists. The logic of the predator commitment law can be applied to people who drive while under the influence of alcohol, who assault their domestic partners or children, who use crack cocaine, or who commit whatever the new "crime-of-the-month" happens to be. ${ }^{149}$

\section{III}

Substance Abusers: A Population at Greater Risk of Crvil COMMITMENT AFTER Hendricks

General commitınent statutes using the broader "mental abnormality" criteria authorized by Hendricks would likely pose great risk to substance abusers. Recent history has shown that courts and Congress are willing to limit constitutional protections in drug-related cases. Moreover, even prior to the diminution of constitutional constraints on involuntary confinement

146. DSM-IV, supra note 18 , at xxvii.

147. In re Marquardt, 427 N.E.2d 41 1, 414 (IIl. App. Ct. 1981).

148. Jules B. Gerard, The Usefulness of the Medical Model to the Legal System, 39 RuTGERS L. REv. 377, 386 (1987).

149. John Q. La Fond, Washington's Sexually Violent Predator Law: A Deliberate Misuse of the Therapeutic State for Social Control, 15 U. PUGET Sound L. REV. 655, 698-99 (1992) (referring to Washington State's SVP law, after which Kansas's was modelcd). 
as a result of Hendricks, some states attempted to use civil commitment statutes to confine substance abusers, albeit with limited success. ${ }^{150}$ Now that the boundaries of civil commitment have widened, attempts to commit substance abusers will likely face few constitutional roadblocks other than the procedural standards established by Addington.

\section{A. The Court's Willingness to Push Constitutional Limits in the "War on} Drugs"

In recent years, the Supreme Court and Congress have demonstrated a willingness to stretch constitutional limits where the "War on Drugs" is involved. For example, Fourth Amendment jurisprudence allowing states to override individuals' rights against unreasonable search and seizure has recently developed to allow drug testing in situations that do not immediately threaten the public safety. ${ }^{151}$ Additionally, asset forfeiture laws now allow the seizure of property used in drug transactions without substantial procedural requirements, despite Fifth Amendment protections of property. ${ }^{152}$ These are just some of the recent trends that demonstrate Congress's and the Court's willingness to enforce constitutional protections less rigorously for substance abusers than they might for other populations.

\section{The "Special Needs" Exception to the Fourth Amendment}

The Fourth Amendment guarantees freedom from unreasonable searches. ${ }^{153}$ Courts have generally interpreted this as requiring law enforcement agents to obtain a judicial warrant before searching an individual's person or property. ${ }^{154}$ The Fourth Amendment explicitly provides that warrants may not be issued absent probable cause. ${ }^{155}$ However, the Supreme Court has held that a search can be constitutional even in the absence of probable cause if "special needs, beyond the normal need for law enforcement, make the warrant and probable-cause requirement impracticable." 156 In 1989, the U.S. Supreme Court decided two cases that expanded this exception to encompass suspicionless drug testing. ${ }^{157}$

150. See infra Part III.B.

151. See infra Part III.A.1.

152. See infra Part III.A.2.

153. U.S. CONST. amend. IV ("The right of the people to be secure in their persons, houses, papers, and effects, against unreasonable searches and seizures, shall not be violated, and no Warrants shall issue, but on probable cause ....").

154. See, e.g., Skinner v. Ry. Labor Executives' Ass'n, 489 U.S. 602, 619 (1989).

155. U.S. CONST. amend. IV.

156. Vernonia Sch. Dist. $47 J$ v. Acton, 515 U.S. 646, 653 (1995) (quoting Griffin v. Wisconsin, 483 U.S. 868,873 (1987)).

157. See Skinner, 489 U.S. 602; Nat'I Treasury Employees Union v. Von Raab, 489 U.S. 656 (1989). 
In Skinner v. Railway Labor Executives' Ass' $n^{158}$ and National Treasury Employees Union v. Von Raab, ${ }^{159}$ the Court held that statecompelled urine collection for the purpose of drug testing constitutes a search under the Fourth Amendment. In Skinner, railroad employees involved in train accidents and other safety violations were subjected to drug testing in the absence of individualized suspicion of drug use, and thus in the absence of a warrant. ${ }^{160}$ The Court reasoned that whether a warrantless search meets the "reasonableness" requirement of the Fourth Amendment is "judged by balancing its intrusion on the individual's Fourth Amendment interests against its promotion of legitimate government interests."161 Under this test, the Court found the state had a compelling interest in preventing train crashes that outweighed the employees' privacy interests. ${ }^{162}$ Using the same balancing test, the Von Raab Court upheld a Customs Service program that required drug testing as a condition of employment in positions directly involving drug interdiction or the possession of firearms. ${ }^{163}$

Skinner and Von Raab both suggest that when public safety is at stake the government has a compelling interest im ensuring that certain individuals are not using drugs, and that such an interest may supersede an individual's right to privacy. However, the Skinner balancing test has since been used in contexts where, strictly speaking, public safety is not the compelling interest.

In Vernonia School District $47 J$ v. Acton, the Supreme Court applied the Skinner balancing test and determined that it was permissible for a public school district to drug test student-athletes as a prerequisite to their participation in interscholastic athletics. ${ }^{164}$ The school district was concerned with the rates of drug use by its students, which were reaching "epidemic proportions"; the school district had reason to believe that student-athletes were largely responsible for the problems. ${ }^{165}$ The Supreme Court weighed this compelling interest against the student-athletes' privacy interests. The Court determmed that student-athletes had a diminished expectation of privacy, as evidenced by the doorless toilet stalls, group showers, and other features of public school locker rooins; the Court also noted that " $[\mathrm{b}] \mathrm{y}$ choosing to go out for the team, [student-athletes] voluntarily subject themselves to a degree of regulation higher than that imposed on

158. Shinner, 489 U.S. at 617.

159. Von Raab, 489 U.S. at 665.

160. Shinner, 489 U.S. at 609-13.

161. Id. at 619 .

162. Id. at 628.

163. Von Raab, 489 U.S. at 656.

164. 515 U.S. 646,650 (1995).

165. Id. 
students generally." 166 Given this reduced privacy expectation, the school district's interest in stemming the drug epidemic was sufficient to warrant drug testing without individualized suspicion. ${ }^{167}$

In Todd v. Rush County Schools ${ }^{168}$ the Seventh Circuit applied a broad interpretation of Vernonia that pushed the limits of the "special needs" exception even further. In Todd, a school district policy required any student who drove to and from school or participated in any extracurricular activity to submit to random drug testing. The policy applied not only to athletes, but also to students in groups such as Future Farmers of America, the Library Club, the Student Council, and the Fellowship of Christian Athletes. ${ }^{169}$ The school district did not claim to be experiencing a drug epidemic as in Vernonia, nor did it claim that the students it targeted were responsible for a disproportionate amount of existing drug use. Moreover, many of the students subject to testing in Todd did not relinquish their expectations of privacy by participating in activities requiring use of group locker rooms or otherwise voluntarily subjecting themselves to a higher degree of regulation.

The Seventh Circuit noted that the population subjected to testing in this case was broader than that in Vernonia ${ }^{170}$ but did not acknowledge the other big distinctions, including the lack of an "epidemic" and the fact that the non-athletes had not voluntarily accepted a lower standard of privacy. Ignoring these distinctions, the court failed to provide a convincing rationale (or any rationale, for that matter) as to why the Vernonia rule should be extended, saying only: "The difference between the cited cases and the present one is that here the testing is also required of those engaging in other extracurricular activities. However, we find that the reasoning compelling drug testing of athletes also applies to testing of students involved in extracurricular activities." 171

While the goal of public safety behind Skinner and Von Raab arguably justifies an exception to the constitutional standard for reasonable searches, Todd cannot be justified in the same way. Unlike when substance users drive trains or carry guns in law enforcement jobs, the threat to public safety caused by a Future Farmer of America using drugs as a teenager is

166. Id. at 657 .

167. Id. at $657,662-63$.

168. 133 F.3d 984 (7th Cir. 1998).

169. Id. at 984.

170. Id. at 986.

171. Id. It should be noted that the Eighth Circuit upheld a similar drug testing policy in 1999 in Miller v. Wilkes, 172 F.3d 574 (8th Cir. 1999), vacated on other grounds, 1999 U.S. App. LEXIS 13289 (8th Cir. June 15, 1999). However, another case with almost identical facts and results in the district court was recently reversed by the Tenth Circuit. See Earls v. Bd. of Ed., 115 F. Supp. 2d 1281 (W.D. Okla. 2000), rev'd, 242 F.3d 1264 (10th Cir. 2001), cert. granted, 122 S. Ct. 509 (2001). A petition for certiorari was recently granted, presumably so that the Supreme Court can resolve this circuit split. 
insufficient to warrant overriding the Fourth Amendment. These cases demonstrate federal courts' willingness to stretch the limits of the narrowly-designed "special needs" exception in order to fight the War on Drugs. ${ }^{172}$ If the Supreme Court upholds these drug-testing policies, it will again demonstrate its willimgness to push constitutional boundaries in order to fight substance use and abuse in this country.

\section{Civil Asset Forfeiture and the Fifth Amendment}

Civil asset forfeiture presents another assault on the civil rights of drug users, again demonstrating Congress's and courts' willingness to stretch constitutional boundaries when dealing with drug users. Civil asset forfeiture permits the state to seize any property when there is probable cause to believe that the property is somehow connected to the illegal drug trade, or to another targeted felony. ${ }^{173}$ In other words, the state can take property ostensibly connected to the targeted felony without convicting or even atteinpting to prosecute anyone for the crime to which it was connected. In fact, the government does not even have to demonstrate that the owner knew his property was soinehow counected to the crime. By contrast, in the other two common circumstances under which the government may seize property, following a criminal conviction and under eminent domain proceedings, the government is held to strict procedural standards. ${ }^{174}$ By failing to provide any substantial due process protections, civil

172. One U.S. Supreme Court case, Chandler v. Miller, 520 U.S. 305 (1997), did overturn a drugtesting statute. A Georgia statute required candidates for designated offices to undergo a drug test prior to qualifying for nomination or election. The Supreme Court rejected the statute on grounds that the State did not demonstrate a sufficient special need to outweigh the imdividuals' privacy imterests. However, the rejection was not based on a true balancing test, but on the grounds that the State failed to provide any evidence at all of a compelling need. 'Notably lacking in respondents' presentation is any indication of a concrete danger demanding departure from the Fourth Amendment's main rule." Id. at 318-19. This holding does not appear to foreclose any future "speeial need" case where the advocate of the exception provides any evidence of a state interest, and thus does not serve to narrow the scope of the exception in any meaningful way.

173. Dan Gardner, How the Drug War Is Eroding Our Civil Liberties, The OtTawa CrTizen, September 12, 2000, at A1. The legislation regarding civil asset forfeiture in relation to illegal drugs is codified at 21 U.S.C. $\$ 881(2000)$. Civil asset forfeiture is also permissible in several other contexts, such as in connection with money laundering. 18 U.S.C. $\$ 1956$ (1996). Additionally, some states have developed civil asset forfeiture statutes that reach nearly every state-level felony. See David B. Smith, Asset Forfeiture: A Serious Threat to Our Property Rights, 2 PERSP. ON. Legis. Reg. \& LITIG. 10, 11 (1998). However, as will be discussed infra, the drug-related asset forfeiture statute is much broader and therefore even more dangerous to civil rights than other types of civil asset forfeiture.

174. See Gardner, supra note 173 (stating that traditional criminal law permits the state to seize any property shown to be the fruits of a crime only after a defendant has been convicted (found guilty beyond reasonable doubt) of that crime); 26 AM. JuR. 2D EMINENT Domain $\$ 7$ (2d ed. 1996) (explaining that in eminent domain proceedings, due process requires "that the property owner be given reasonable notice of, and an opportunity to be heard and offer evidence $\mathrm{m}$, proceedings to determine compensation for the property taken for a public use"). 
asset forfeiture raises serious constitutional issues. ${ }^{175}$ Moreover, because of special features of the Drug Abuse Prevention and Control Act, ${ }^{176}$ which created a broader range of forfeiture options and incentives for law enforceinent agents in drug-related cases, ${ }^{177}$ drug users are disproportionately affected. Thus, civil asset forfeiture provides another example of the willingness of Congress and the courts to enforce constitutional protections less rigorously when it comes to substance abusers.

The Fifth Amendment guarantees that "[n]o person shall be... deprived of life, liberty, or property without due process of law; nor shall private property be taken for public use, without just compensation."178 According to the Supreme Court, the purpose of the due process requirement with respect to property is "not only to ensure abstract fair play to the individual ... [but also] to protect his use and possession of property from arbitrary encroachment-to ininimize substantively unfair or mistaken deprivations of property ...." ${ }^{\prime 179}$ Although there are no per se requirements that satisfy due process, the processes afforded property owners following criminal convictions and under eminent domain proceedings are instructive.

Following a criminal conviction the state nay seize any property shown to be a fruit of the illegal activity. ${ }^{180}$ The criminal conviction process contains several procedural protections for the defendant, including the requirement that the state appoint an attorney if the defendant cannot afford one, and the right of the defendant to a trial by jury. The defendant also has a right against compelled self-incrimination, and no adverse inferences can be drawn from his refusal to speak. ${ }^{181}$

The government must also meet substantial procedural requirements before it inay proceed under eminent domain, the doctrine under which the government may seize private land for its own purposes. In eminent domain proceedings, due process requires "that the property owner be given reasonable notice of, and an opportunity to be heard and offer evidence in, proceedings to determine compensation for the property taken for a public use." 182 Not only are owners guaranteed notice and a right to be heard but,

175. See generally David Benjamin Ross, Comment and Note, Civil Forfeiture: A Fiction that Offends Due Process, 13 Regent U. L. Rev. 259, 260 (2000-01) (arguing that civil asset forfeiture "offends traditional notions of due process").

176. Codified at 21 U.S.C. $\$ 881(2000)$. The amendment allowing forfeiture is found at (a)(7), and was implemented in 1984.

177. See Smith, supra note 173, at 22-23.

178. U.S. ConST, amend. V.

179. United States v. James Daniel Good Real Property, 510 U.S. 43, 53 (1993) (internal citations omitted).

180. Gardner, supra note 173.

181. See Arthur W. Leach and John G. Malcolm, Criminal Forfeiture: An Appropriate Solution to the Civil Forfeiture Debate, 10 GA. ST. U. L. Rev. 241, 242 (1994).

182. 26 AM. JUR. 2D EMinent Domain $§ 7$ (2d ed. 1996). 
unlike victims of civil or criminal forfeiture actions, they also receive compensation for the value of the property.

By contrast, constitutional guarantees in civil asset forfeiture are lacking in several ways. To begm with, only an extremely minimal showing is required before the government may seize property. The government need only show that there is probable cause to believe the property is connected to a targeted felony. ${ }^{183}$ Such a showing shifts the burden to the owner to prove, by the much higher standard of "a preponderance of the evidence," that the property was not involved $\mathrm{m}$ an illegal transaction. ${ }^{184}$ Moreover, the property is not returned if the owner is not convicted; in fact, in $80 \%$ of forfeiture cases criminal charges are never even brought. ${ }^{185}$

Perhaps even more astounding is that under civil asset forfeiture, im contrast to any criminal proceedings, the state is not required to provide counsel for indigent defendants. ${ }^{186}$ Nor is the defendant entitled to use the property allegedly subject to forfeiture to obtam money to pay counsel. ${ }^{187}$ Lack of counsel can be especially problematic in civil asset forfeiture contests. First of all, an individual who intends to contest has only ten days after the government files suit to respond. ${ }^{188}$ Second, if he is facing concurrent criminal charges, there is a grave risk of self-incrimination. ${ }^{189}$ And, if he chooses not to speak im order to prevent self-incrimination, adverse inferences may be drawn from his silence. ${ }^{190}$ Without an attorney, an individual would have extreme difficulty wading through this legal minefield. Thus, the processes required by civil asset forfeiture, especially when compared with other property seizure tactics that satisfy due process, are arguably not sufficient to protect an individual from substantively unfair or mistaken deprivations of property, and do not ensure fair play.

Although civil asset forfeiture laws can reach participants in various areas of criminal activity, drug users are among the most severely impacted, for several reasons. To begin with, although traditionally private homes and real estate were not subject to forfeiture regardless of their connection to criminal activity, in 1984 the federal drug civil forfeiture statute was amended to permit forfeiture of real property that facilitates drug offenses. ${ }^{191}$ In advocating this amendinent, law enforcement agencies explained to Congress that this would be an effective way to target big drug operations and to forfeit "stash houses and clandestine landing strips used

183. See Smith, supra note 173 , at 33 .

184. See id. (citing 19 U.S.C. $\$ 1615$ (1984)).

185. Smith, supra note 173, at 36; Gardner, supra note 173.

186. Smith, supra note 173 , at 31 .

187. Id. at 13 .

188. Id. at 32-33.

189. Id. at 33 .

190. Leach and Malcom, supra note 181, at 242.

191. 21 U.S.C. $\$ 881$ (e) (2000). 
by drug pilots." 192 Despite these high aspirations, the more frequent victims of the new law have been individual drug dealers and those who have a few marijuana plants, many of whom have forfeited their homes. ${ }^{193}$ The slightest connection between a home and a drug use has been found sufficient; in one case, "the use of a home telephone to negotiate one two-ounce cocaine sale was enough" to warrant forfeiture of the entire home. ${ }^{194}$

Another amendment in 1984 allowed money and property forfeited to go to the direct benefit of law enforcement; ${ }^{195}$ this engendered what some have called a "bounty-hunter system," whereby law enforcement agencies target the most lucrative forfeiture possibilities, rather than the most serious criminals. ${ }^{196}$ Drug use and drug trafficking often take place on and in conjunction with privately owned property. As mentioned above, a call from a home telephone to arrange a small drug transaction may put the home at risk; likewise, an automobile driven to make a purchase may be forfeited. The profitability of pursuing civil asset forfciture among drug users has made this population a victim of over-vigilant law enforcement, resulting in severe deprivation of due process rights under the Fifth Amendment.

\section{B. Civil Commitment of "Dangerous" Substance Abusers Before and After Hendricks}

Even before Hendricks, many states had attempted to use civil commitment statutes to confine substance abusers, both through specific provisions for the commitment of substance abusers and by applying general commitment statutes to such individuals. These efforts met with limited success. One common point of contention reflected a debate about whether substance abuse met the "mental illness" requirement. However, the acceptance in Hendricks of a broader "mental abnormality" standard, if replicated in general civil commitment statutes, would likely quell that debate, since substance abuse clearly fits under Justice Thomas's formulation of mental abnormality as defined by inclusion in the DSM. ${ }^{197}$ Moreover, the recent developments in "special needs" jurisprudence and civil asset forfeiture law, which demonstrate the limited constitutional protections offered in drug-related cases, suggest that the use of a "mental abnormality" standard in general civil commitment statutes would be

192. Smith, supra note 173 , at 23.

193. Id.

194. Id. (citing United States v. Real Estate Known as 916 Douglas Ave., 903 F.2d 490 (7th Cir. 1990)).

195. 21 U.S.C. $\S 881$ (e).

196. Smith, supra note 173 , at 13-14 (noting also that violent criminals tend to have fewer forfeitable assets than other types of criminals).

197. See supra Part I1.B; see also note 18 (establishing the inclusion of substance abuse disorders and dependence in the DSM). 
constitutionally permissible. At least one recent case applying the Hendricks standard to a substance abuser bears out this conclusion. ${ }^{198}$

\section{The Existence of Specific Provisions for Substance Abusers}

Many states have laws on the books permitting the involuntary commitment of substance abusers in conjunction with a showing of dangerousness. ${ }^{199}$ However, for a variety of reasons, these statutes are rarely used. ${ }^{200}$ First, state and local officials may not be aware they exist. ${ }^{201}$ Very little appears to have been written on the subject between the early $1970 \mathrm{~s}$, after the initial flurry of articles when the statutes were implemented in a number of states, and the late $1980 \mathrm{~s}$, when the Bush Administration suggested the investigation of civil commitment of substance abusers in response to the high level of crack cocaine usage. ${ }^{202}$ This lack of attention suggests that these statutes have largely been forgotten. In addition, commitment statutes for substance abusers are more likely to require that effective treatment is available; ${ }^{203}$ this requirement drastically increases the cost to the state of using these processes. Finally, the allowable period of commitment is generally shorter than for the mentally ill. ${ }^{204}$ These factors limit the practical utility of commitment statutes designed for substance abusers.

\section{The Use of General Civil Commitment Statutes to Confine}

"Dangerous" Substance Abusers Before Hendricks

Even states with civil commitment provisions specifically for substance abusers have sometimes instead tried to commit those individuals under the general civil commitment statutes designed for the mentally ill rather than under the substance-abuse-specific statutes. States without specific substance-abuser provisions have also occasionally tried this approach to confine substance-abusing individuals. These attempts met with varied success before Hendricks. ${ }^{205}$

198. See Mercer v. Commonwealth, 523 S.E.2d 213 (Va. 2000).

199. According to one source, approximately $75 \%$ of states as well as the District of Columbia have some form of statutory provisions governing the involuntary commitment of drug users. Garcia \& Keilitz, supra note 17 , at 418.

200. See Thomas L. Hafemeister \& Ali John Amirshahi, Civil Commitment for Drug Dependency: The Judicial Response, 26 Loy. L.A. L. Rev. 39, 43 (1992); MELTON ET. AL., supra note 26 , at 335 .

201. See Hafemeister \& Amirshahi, supra note 200, at 43.

202. See id. at 42-43; see also Garcia \& Keilitz, supra note 17, at 418.

203. Hafemeister \& Amirshahi, supra note 200, at 50.

204. MELTON ET. AL., supra note 26, at 335.

205. It should be noted that there is a dearth of published opinions on these statutes. One obvious reason for this is that they are rarely used. In addition, this field of law is strictly under the purview of the states, where lower court decisions are infrequently published; moreover, many defendants are from modest backgrounds and unlikely to appeal to a higher court. These reasons probably also explain why no substantive due process challenge to the confinement of substance abusers has ever been raised. 
The District of Columbia is one jurisdiction with specific provisions for substance-abusing individuals. ${ }^{206}$ Nonetheless, in In re Stokes, a case involving an attempt to commit an individual for drug addiction, the D.C. Court of Appeals only addressed the statute targeted at the mentally ill. ${ }^{207}$ Ms. Stokes was being treated for a bipolar disorder as an outpatient, but the hospital sought to confine her as an inpatient. The only witness to testify against Stokes was the hospital psychiatrist, who testified as to a variety of alleged aggressive and violent behavior. The court criticized the doctor for not providing sufficient detail, such as dates or frequencies of the behavior. More importantly, however, "the doctor did not associate the behavior with anything other than PCP use." ${ }^{208}$ The court concluded that the hospital could not revoke Stokes's outpatient status because there had been no finding of mental illness. Such a finding was necessary under the Hospitalization of the Mentally Ill Act: ${ }^{209}$ "Drug addiction or intoxication, even though it may produce dangerous behavior, does not constitute a mental illness within the meaning of the ... Act." ${ }^{210}$ No mention was made of the district's statutory provision governing commitment of substance abusers, and Stokes was released.

In a similar holding in Illinois, a state without specific provisions for substance abusers, the appeals court in In re Marquardt rejected the involuntary commitment of a substance-abusing individual under its general civil commitment statute. ${ }^{211}$ The court ruled, as a matter of first impression, that drug abuse does not constitute a mental illness under its civil commitment statute. ${ }^{212}$ A doctor had determined that Marquardt was not subject to depression or psychotic, but was addicted to a synthetic version of herom and was extremely likely to give himself a lethal dose, or at least cause himself serious harm, if released from temporary confinement. ${ }^{213}$

Although the court agreed that the diagnosis established Marquardt's dangerousness, it disagreed with the state's position that the addiction constituted a mental illness. ${ }^{214}$ To support its position that addiction should be considered a mental illness, the state relied on the inclusion of drug dependence in the DSM. ${ }^{215}$ The court rejected this argnment, noting that

206. D.C. CODE ANN. § 24-608 (1981).

207. 546 A. 2 d 356 (D.C. 1988 ).

208. Id.

209. D.C. CoDE ANN. $\S 21-545(b)$ (1981).

210. Stokes, 546 A.2d at 363 .

211. 427 N.E.2d 41 1, 414-15 (Ill. App. Ct. 1981) (considering ILL. REv. STAT. ch. 911/2, § 1-119 (1979)).

212. 427 N.E. $2 d$ at 414 .

213. Id. at 413 .

214. Id. at 413-15.

215. Id. at 413. 
"considering the other conditions that are classified as mental disorders by DSM, this evidence is patently insufficient.".216

By contrast, the Oregon Court of Appeals was willing to find that "acute and chronic alcoholism" constituted a mental illness sufficient to satisfy the requirement of the state's general commitment statute. ${ }^{217}$ However, the court explicitly relied on Oregon's legislative history surrounding civil commitment of substance abusers. The legislature had previously repealed a bill that had provided for the commitment of "addicts"; the accompanying testimony explained that "[d]rug addicts can be civilly committed under the general commitment statutes, with the same criteria for commitment as with other mental disorders." 218 Thus, the court held that the legislature intended to provide for civil commitments of chronic alcoholics and drug addicts who met the additional requirement of constituting a danger to theniselves or others. ${ }^{219}$

\section{The Use of General Civil Commitment Statutes to Confine "Dangerous" Substance Abusers After Hendricks}

Mercer v. Commonwealth, ${ }^{220}$ a Virginia Supreme Court case and one of the few published opinions applying the Hendricks decision to non-SVP civil commitment, ${ }^{221}$ clearly demonstrates how Hendricks has changed the face of civil commitment of substance abusers. Mercer contested her continued commitment after being found not guilty of criminal charges by reason of insanity; she had already conpleted her initial thirty-day evaluation period. ${ }^{222}$ In order to confine Mercer under its general commitment statute, Virginia was required to show that she had a mental illness. ${ }^{223}$ Two doctors diagnosed Mercer with both antisocial personality disorder (“APD”) and

216. Id. at 415. The court did not foreclose the possibility that in the future the State could provide sufficient evidence that drug abuse should be considered a mental illness; however, to date there is no published opinion demonstrating that the State has succeeded.

217. In re Smith, 629 P.2d 120, 122 (Or. Ct. App. 1984) (discussing OR. Rev. STAT. $\$ 426.005$ (date omitted)).

218. Id. at 122-23 (quoting Exhibit A, Senate Committee on Judiciary, Senate Bill 75, January 22, 1975).

219. Id. at 124. Unlike the D.C. and Mllinois statutes, which provide for an infinite duration, the Oregon statute limits the length of initial confinement to 180 days. See Beis, supra note 5, at 366 . This may partially explain Oregon's broader application of its statute, as its potential to infringe on an individual's liberty right is limited in duration.

220. 523 S.E.2d 213 (Va. 2000).

221. A recent Westlaw search for cases applying Hendricks turned up only six cases that did not relate to the commitment of sexual predators. Mercer was the only case addressing the possibility of commitnent on the basis of substance abuse without proof of concurrent mental illness (in the remaining cases there was proof of a dual diagnosis).

222. Id. at 238 .

223. Id. Virginia's statute is similar to most states' general commitment statutes, which require a showing of inental illness and dangerousness. It is not unlike the statute at issue in Foucha, discussed supra Part 1.B.2.b, where the Supreme Court refused to expand the mental illness category. 
polysubstance dependence ("PSD"). ${ }^{224}$ However, the doctors disagreed about whether Mercer's APD was a mental illness. ${ }^{225}$

Because of the disagreement regarding Mercer's APD, the lower court based its finding that Mercer was mentally ill on her history of drug abuse and addiction. ${ }^{226}$ The lower court stressed that " the case does not rise and fall on whether the Court finds that Mercer's [APD] is a mental illness."'227 Because Mercer's APD was irrelevant to the lower court's decision, the Virginia Supreme Court, on appeal, only reviewed whether the lower court properly found drug abuse and addiction to constitute a mental illness. ${ }^{228}$

The Virginia Supreme Court noted that the relevant code section did not directly address whether PSD qualified as a mental illness for the purpose of continued confinement of an insanity acquittee. ${ }^{229}$ It then looked at the factors the code required courts to consider in determining whether to continue post-acquittal confinement of an insanity acquittee: the extent to which the acquittee is mentally ill or mentally retarded; the likelihood that the acquittee will engage in conduct that is dangerous to himself or others in the foreseeable future; the likelihood that the acquittee can be adequately controlled with outpatient treatment; and "[s]uch other factors as the court deems relevant. $" 230$

The court next cited the critical Hendricks language, reiterating Justice Thomas's claim that the U.S. Supreme Court has never "'required State legislatures to adopt any particular nomenclature... [leaving] to legislators the task of defining terms of a medical nature that have legal significance." "231 On this basis, the court concluded that the determination of whether Mercer suffered from a mental illness was a question of fact that should be resolved by the lower court based on the relevant statutory provisions and the reports and testimony of the experts. ${ }^{232}$ The Virginia Supreme Court found that the lower court had resolved the conflict in testimony and had made a factual determination that PSD was a mental illness. ${ }^{233}$ Applying a "clearly erroneous" standard of review, the court affirmed, holding that " $[t]$ here is evidence in the record to support the court's conclusion that Mercer suffers from a mental illness and presents a

224. Id.

225. Id. at 238-39. The doctors agreed that APD is a mental disorder described in the DSM, but disagreed on whether that was the appropriate benchmark for mental illness under the state law.

226. Id. at 239 n. 4 .

227. Id. (citation omitted in original).

228. Id. at 240 .

229. Id. at 241 .

230. Id. at 242 .

231. Id. (quoting Kansas v. Hendricks, 521 U.S. 346, 359 (1997)).

232. Id. at 242.

233. Id. at 243. 
substantial risk of bodily harm to other persons because of her long history of drug abuse, drug addiction, and violence. ${ }^{9234}$

If Mercer is any indication, state courts and legislators are beginning to recognize the new leeway granted by the Supreme Court in Hendricks. In fact, Mercer arguably expanded that leeway. Hendricks made clear that states can expand the scope of civil commitment statutes by using broad criteria such as "mental abnormality" rather than narrower, traditional "mental illness." Mercer appears to go a step further; rather than enacting new legislation, Virginia just created its own definition of mental illness, ignoring the conventional wisdom that mental illness is a definable term. ${ }^{235}$ Thus, there does not seem to be any question that under the Hendricks rationale substance abusers can be confined pursuant to broadened statutory requirements of either mental abnormality or mental illness, so long as there is an additional showing of dangerousness. What has yet to be explored, however, is the elasticity of the definition of "dangerousness."

\section{Meeting the Statutory Requirements After Hendricks: The Concept of "Dangerousness"}

The wide net cast by the newly allowable mental abnormality standard from Hendricks, or the "it means what we want it to mean" mental illness standard from Mercer, is not the only worry for substance abusers. As this Part will explore, substance abuse is a common risk factor for violence. Although the science of predicting dangerousness is widely known to be inconclusive, courts consistently allow the testimony of "experts" in commitment hearings. As a result, substance abusers have reason to fear that their drug use will be used as evidence of dangerousness for purposes of civil commitment.

\section{Substance Abuse as Danger to Self}

To date, the parties to U.S. Supreme Court civil commitment cases have largely been unsympathetic characters: Addington was assaultive and mentally ill, Foucha had been acquitted of aggravated burglary by reason of insanity, and Hendricks was a child molester. ${ }^{236}$ To invoke Justice Brennan, they were "hardly ... model representative[s] of our Nation."237

234. Id.

235. The Kansas legislature explicitly recognized that mental illness was narrow; that was an admitted reason for the new broader statute. See supra Part I.B.2.c. For a discussion of the psychiatric community's definition of mental illness and its difference from the larger category of mental disorders, see supra notes 79-80 and accompanying text.

236. Addington v. Texas, 441 U.S. 418 (1979) (discussed supra Part I.B.2.a); Foucha v. Louisiana, 504 U.S. 71 (1992) (discussed supra Part I.B.2.b); In re Hendricks, 912 P.2d 129 (Kan. 1996) (discussed supra Part I.B.2.c).

237. Haig v. Agee, 453 U.S. 280,319 (1981) (Brennan, J., dissenting) (explaining that bad facts make bad laws because unlikable characters do not necessarily elicit the most just response). 
In truth, people may not be so opposed to applying a broad interpretation of mental abnormality if it results in commitment of individuals who genuinely appear dangerous but who are not mentally ill.

However, some of the published state cases reveal that not only unquestionably violent and dangerous people are at risk after Hendricks. Opinions may differ, for example, as to whether Marquardt, whose doctor wanted him confined to prevent a narcotic overdose, should have been left in peace to kill himself as he apparently wished, assuming he was only hurting himself and presented no danger to others. Even if one agrees that individuals should not be allowed to commit suicide through drug use, finding that someone poses sufficient danger to himself to warrant commitment because of drug use is a slippery slope. Marquardt's doctor testified that he was likely to kill himself or cause serious harm. However, most drugs can cause serious harm, including legal drugs such as nicotine, alcohol, and prescription medications. If one were to combine Marquardt's premise that the possibility of self-administering a harmful dose of a drug satisfies the dangerousness requirement ${ }^{238}$ with Mercer's holding that drug abuse and addiction fulfill the mental illness requirement, then any drug abuser, and potentially even any cigarette smoker, could be civilly committed.

Admittedly, these arguments seem somewhat far-fetched. At the very least, one might respond that the contention that a cigarette smoker presents a danger to himself of the maguitude or imminence required by state civil commitment statutes does not fulfill the clear and convincing standard of proof required by Addington. Nonetheless, these arguments demonstrate the potential slippery slope problem caused by Hendricks's broadening of the category of mental disorders considered sufficient for civil commitment in conjunction with a showing of dangerousncss. Further, they illustrate the relevance of an issue not directly addressed by the main Supreme Court cases on civil commitment: what constitutes a prediction of dangerousness? ${ }^{239}$ More specifically, if, as Mercer portends, substance abuse can constitute a mental illness or abnormality sufficient to satisfy the first statutory requirement for civil commitment, what evidence will actually suffice to create a prediction of dangerousness sufficient for the second prong?

238. The court did find that Marquardt was "clearly dangerous to himself"; he was released on the grounds that his addiction did not satisfy the "mental illness" requirement. In re Marquardt, 427 N.E.2d 411, 413 (Ill. App. Ct. 1981); see also In re Evans, 408 N.E.2d 33 (1980).

239. Addington set a standard of proof for showing future dangerousness, but did not directly address what a successful showing would entail. 


\section{Predictions of Dangerousness to Others}

a. The Accuracy of Mental Health Professionals' Predictions of

\section{Dangerousness}

Experts on dangerousness and mental health widely agree that predictions of dangerousness and violence are far from an exact science. ${ }^{240}$ For example, one well-respected study found that "psychiatrists and psychologists are accurate in no more than one out of three predictions of violent behavior over a several-year period among institutionalized populations that had both committed violence in the past (and thus had high base rates for it) and who were diagnosed as inentally ill."241 In another survey of the seven most commonly cited studies on the ability of mental health professionals to predict dangerousness, between 54 and $92 \%$ of individuals predicted to act violently over a three to five year follow-up period failed to do so. ${ }^{242}$ Most of these studies were conducted over twenty years ago, and some researchers promise that accuracy in predicting violence is improving. ${ }^{243}$ Still, as one author cautions, "[d]espite 25 years of research, social scientists have barely scratched the surface of risk assessment as a predictive tool." ${ }^{.244}$

\section{b. The Law of Dangerousness Prediction}

"This area of law ... presents a paradox in which judges seemingly take the most lenient approach toward scientific evidence involving some of the most controversial science to enter the courtroom."245 Ironically, courts have repeatedly acknowledged the imperfection of dangerousness evidence as mere asides to discussions of loftier constitutional issues, such as the appropriate burden of proof. For example, in discussmg the requisite standard of proof in Addington, the Court acknowledged that the debate about standard of proof was largely symbolic. Explaining that any deprivation of an individual's liberty requires substantial due process protection (and thus greater than the minimum standard of proof), the Court also adimitted to "a belief that the varying standards tend to produce comparable

240. See, e.g., Predictions of Violence, supra note 11, at 308-09; Christopher Slobogin, Dangerousness and Expertise, 133 U. PA. L. REv. 97, 100-11 (1984).

241. Predictions of Violence, supra note 11, at 308 (citation omitted).

242. Slobogin, supra note 240, at 110-11.

243. See, e.g., Kirk Heilbrun \& Gretchen Witte, The MacArthur Risk Assessment Study: Implications for Practice, Research, and Policy, 82 MARQ. L. REv. 733, 733 (1999) (noting the "significant theoretical and empirical advances in this area during the last decade"); Joseph T. McCann, Risk Assessment and the Prediction of Violent Behavior, 44 FED. LAw. 18, 19 (1997) (commenting that over the past years mental health professionals' predictions of violence are "better than chance").

244. Randy K. Otto, On the Ability of Mental Health Professionals to "Predict Dangerousness": A Commentary on Interpretations of the "Dangerousness" Literature, 18 LaW \& PSYCHOL. REV. 43, 67-68 (1994).

245. Predictions of Violence, supra note 11, at 288. 
results" because there is guesswork in these predictions. ${ }^{246}$ With respect to the rejection of the strictest standard, Justice Burger wrote, "[g]iven the lack of certainty and the fallibility of psychiatric diagnosis, there is a serious question as to whether a state could ever prove beyond a reasonable doubt that an individual is both mentally ill and likely to be dangerous."247

Addington is only one of many cases in which the Court referenced the inaccuracy of dangerousness predictions but failed to address the problematic nature of this evidence in its constitutional analyses of statutes that require its use. ${ }^{248}$ In Heller v. Doe, the Court conducted a rational basis review of a Kentucky civil commitment statute that required a different standard of proof for mentally ill individuals than for mentally retarded individuals. ${ }^{249}$ In the course of finding that the statute did not violate the Equal Protection Clause, the Court noted that "many psychiatric predictions of future violent behavior by the mentally ill are inaccurate."250

To the extent that courts actually address evidentiary standards for expert testimony regarding predictions of dangerousness, the District of Columbia Court of Appeals seems to have set the standard in In re Melton. ${ }^{251}$ The court began by referencing an earlier case in that district, Dyas $v$. United States. ${ }^{252}$ Dyas employed the three-part test for admissibility of expert testimony that was set out in McCormick on Evidence ${ }^{253}$ and adopted in most states. ${ }^{254}$ Under the first two parts of the McCormick test, the subject matter of an expert's testimony must be beyond the understanding of the average lay person and the expert must have sufficient skill or expertise in the field to aid the trier of fact in its search for the truth. Under the third part of the test, the expert's testimony is inadmissible if "the state of the pertinent art or scientific knowledge does not permit a reasonable opinion to be asserted even by an expert."255

246. Addington v. Texas, 441 U.S. 418, 425-26 (1979).

247. Id. at 429 .

248. See, e.g., Barefoot v. Estelle, 463 U.S. 880, 900-01 (1983) (acknowledging research presented by petitioner and Amicus Curiae American Psychiatric Association that demonstrated that psychiatrists' predictions are wrong more often than right, but holding that procedural requirements such as cross-examination and impeachment protect defendants from any constitutional violation); Schall v. Martin, 467 U.S. 253, 294 (1984) (Marshall, J., dissenting) (reviewing the violence prediction literature and concluding that violence is "virtually wholly unpredictable"); People v. Murtishaw, 631 P.2d 446, 469 (Cal. 1981) (commenting that in cases where the trier of fact is required to determine whether a defendant is dangerous, "expert prediction, unreliable though it may be, is often the only evidence available to assist the trier of fact").

249. 509 U.S. 312 (1993).

250. Id. at 324 .

251. 597 A.2d 892 (D.C. 1991).

252. Id. at 897 (citing 376 A.2d 827,832 (D.C. 1977)).

253. Edward W. Cleary, McCormick on Evidence $\S 13$ (cited in Predictions of Violence, supra note 11, at 291).

254. See Joshua Dressler, Understanding Criminal law 218 (2d ed. 1995).

255. Cleary, supra note 253. 
The third criterion had traditionally been the gatekeeper for questionable scientific evidence such as dangerousness prediction, and it was the basis for Melton's argument that psychiatrists' assessment of his dangerousness should not be admitted. ${ }^{256}$ At the time of the Dyas case, federal courts determined whether a field of science was eligible for expert testimony by applying the Frye test, under which scientific evidence was only admissible if "thc principle upon which it is based is 'sufficiently established to have gained general acceptance in the particular field in which it belongs."'257 Although the District of Columbia courts are not bound by federal precedent, Melton argued for application of the Frye test, which would suggest that "the present state of psychiatric knowledge does not permit the District's witnesses to express opinions on the question of Melton's dangerousness to himself or others, within the meaning of the third prong of Dyas."258

The court rejected this argument primarily on the theory that evidentiary rules should not contradict the statutory law of the district. According to the court, the legislature had clearly determined, as evidenced by the D.C. civil commitment statute, that predictions in this science could and should be made for purposes of civil commitment. ${ }^{259}$ The court held that it would be illogical to interpret the evidentiary rules in a way that would contradict legislative intent:

[T]o accept appellant's theory that psychiatrists cannot predict dangerousness, and therefore should not be permitted to testify on this issue, would nullify the entire legislative scheme for treatment of mentally ill persons in the District of Columbia. The legislature has effectively decided that "the state of the pertinent art or scientific knowledge [permits] a reasonable opinion to be asserted ... by an expert,"... and we would be impermissibly intruding upon a legislative prerogative if we were to challenge that judgment. ${ }^{260}$

To the extent that other courts havc even addressed the issue of evidentiary standards, they have largely followed the Melton court's approach and deferred to legislative determinations that such predictions are worthwhile. ${ }^{261}$ Moreover, in 1993 the U.S. Supreme Court announced a new test, more liberal than Frye, for federal courts to use in determining whether to admit expert testimony in an undeveloped field of science. Under Daubert v. Merrell Dow Pharmaceuticals, Inc. ${ }^{262}$ scientific evidence is admissible

256. Melton, 597 A.2d 892,898 (D.C. 1991).

257. Id. at 20 (quoting Frye v. United States, 293 F. 1013, 1014 (D.C. Cir. 1923)).

258. Melion, 597 A.2d at 898 .

259. Id. at 899 (discussing D.C. CoDE $\$ 21-522$ (1989)).

260. Id. at 900 (quoted in Predictions of Violence, supra note 11, at 292).

261. Predictions of Violence, supra note 11, at 292.

262. 509 U.S. 579 (1993). 
if "the reasoning or methodology underlying the testimony is scientifically valid and... properly can be applied to the facts in issue."263 In other words, scientific evidence may be admissible even if it has not yet gained general acceptance in its field. Thus, the Daubert rule substantially broadens the range of allowable expert testimony. While only federal courts are required to apply the Daubert standard, some states have already adopted it, and more may continue to do so. ${ }^{264}$

Given the apparent willingness of courts to defer to legislative determinations of what types of evidence should be admissible, as well as the liberalization of federal standards for expert testimony, dangerousness predictions will likely continue to play an important role in civil commitment cases, despite evidence that such predictions are often inaccurate. "In effect, therefore, the evidentiary determination in the sundry contexts in which predictions of violence are relevant is limited to assessing the qualifications of the proffered experts."265

\section{c. Dangerousness and Substance Abuse}

Numerous studies have attempted to determine the connection between violence and mental disabilities. ${ }^{266}$ One common theme among them is that drug use is a substantial risk factor in predicting violence. In particular, substance abuse alone was a much higher predictor of future violence than mental illness alone, and the highest rates of violence occurred among individuals who were both mentally ill and substance abusers. ${ }^{267}$

One important study in this field stemmed from data collected from 19,182 participants from five sites around the United States, all of whom completed an extensive survey regarding their mental and emotional functioning, their substance use patterns, and any instances of violent behavior in the previous year. ${ }^{268}$ The frequency of violence among those with no pattern of substance abuse or mental disability was $2 \%$; it increased to 10 $12 \%$ for those diagnosed with obsessive-compulsive disorder, panic disorder, major depression, major depression with grief, bipolar disorder,

263. MeLTON ET AL., supra note 26, at 21 (quoting Daubert, 509 U.S. at 592-93).

264. Id. at 21 (noting that in the two years after the ruling, eleven states had adopted the standard and five had rejected it; many others had cited the case but not ruled one way or the other).

265. Predictions of Violence, supra note 11, at 292-93.

266. See, e.g., Violence and Mental Disorder: Developments in RisK Assessment (John Monahan \& Henry J. Steadman eds., 1994).

267. See Heilbrun \& Witte, supra note 243 (reviewing several studies with similar results); Jeffrey W. Swanson, supra note 20; MacArthur Violence Risk Assessment Study, Executive Summary (April, 1999) (on file with author) [hereinafter MacArthur Study].

268. See Heilbrun \& Witte, supra note 243, at 742-43 (discussing Psychiatric Disorders in America: The Epidemiologic Catchment Area Study (Lee N. Robins \& Darrel A. Reiger eds., 1991)). Violence was measured by self-reported behavior including fighting with a spouse or partner or another individual, or physically abusing a child. Id. at 743 . 
schizophrenia, or schizophreniform disorder. ${ }^{269}$ However, substance abuse appeared to be an even stronger risk factor for violence; the rates of violence were substantially higher for those who abused nıarijuana (19\%), alcohol (25\%), or "other drug" (35\%). ${ }^{270}$

The MacArthur Risk Assessment Study, which has been called "the best that has ever been performed in the area of violence and mental disorder," reported similar results. ${ }^{271}$ Given the strong correlation between substance abuse and high rates of violence in both mentally-disordered and non-mentally-disordered populations, as well as the high rates of substance abuse among those who are inentally disordered, the study explored "whether the major risk factors for violence among those with inental disorders are significantly different from violence risk factors for those without mental disorders."272 In other words, the study examined whether the higher rates of violence among the mentally disordered are actually attributable to the high rates of substance abuse among that population.

The results suggested some truth to this theory: "The prevalence of violence is higher among people-discharged psychiatric patients or non-patients-who have symptoms of substance abuse. People who have been discharged from a psychiatric hospital are more likely than other people living $\mathrm{m}$ their communities to have symptoms of substance abuse."273 The study found that the mentally disordered who did not have symptoms of substance abuse had violence prevalence rates equivalent to non-patients who did not have symptorns of substance abuse; however, for the first few months after discharge, the patients with substance abuse had higher rates of violence than substance abusers in the community. ${ }^{274}$ In short, the study found that substance abuse alone is more strongly correlated to violent behavior than mental disorder alone, and that rates of violent behavior are at their highest when both mental disorder and substance abuse are present.

\section{Putting it Together: Hendricks and the Dangerousness of Substance Abusers}

Following Hendricks, it appears that substance abuse is sufficient to constitute a mental abnormality for the purposes of civil commitment. Evidence even suggests that courts are willing to find that substance abuse fulfills the statutory requirement of dangerousness to self. In those courts, a substance abuser could be involuntarily confined just for being a substance

273. MacArthur Study, supra note 267. "Non-patients" were a random sample of people from the same neighborhoods as the discharged patients. Id.

274. Id. 
abuser. Even where substance abuse itself is not deemed substantially dangerous, it might be used as evidence of an individual's proclivity toward violent behavior. Given the evidence that substance abuse is the highest single correlate to future violent behavior, ${ }^{275}$ as well as the relaxed standards courts seem to use in reviewing expert testimony despite the admitted difficulty of predicting dangerousness, it seems likely that courts will contimue to permit expert testimony linking substance abuse to future dangerousness $\mathrm{m}$ civil commitment proceedings.

IV

\section{The Problem with Civilly Committing Substance Abusers}

Before discussing the problems associated with involuntary civil commitment of substance abusers, it is appropriate to briefly address the imminence of this threat. After Hendricks, the constitutionality of the proposal seems fairly clear. But would anybody really suggest such a thimg?

Although there is currently no record of an official proposal to develop such a policy, a recent student comment reviewing alternatives to lengthy incarceration for substance abusers briefly suggests that Hendricks might provide a police power justification for civilly committing substance abusers. ${ }^{276}$ Moreover, another student article suggested using the Hendricks model as a paradigm for civil commitment of domestic violence offenders. ${ }^{277}$ Thus, the idea of applying the new liberal Hendricks criteria for civil commitment to expanded categories of distasteful people has occurred to at least a few law students. In all likelihood, these possibilities will be considered in more depth in the near future. As a result, it is critical to understand why such a policy is unjustified, and to consider ways in which it can be avoided.

This Part will begin by discussing the fundamental nature of liberty and then explore several reasons why a policy of depriving substance abusers of their liberty is unjustified. Deprivation of liberty is most commonly justifled when an individual commits, and is convicted of, a criminal act. In these circumstances the criminal adjudication process provides the due process protections that are constitutionally required before an individual may be deprived of his liberty. However, since civil commitment by definition does not stem from the same process, it caunot be justified in the same way. The primary justifications for non-criminal (civil) restraints are parens patriae, under which the state acts as guardian of an individual

275. See Heilbrun \& Witte, supra note 243.

276. Dess Aldredge Grangetto, Comment, Reducing Recidivism by Substance Abusers Who Commit Drug and Alcohol Related Crimes, 10 J. Contemp. Legal Issues 383, 398 (1999) ("Hendricks suggests that the state's police power could also be used to impose mandatory post-sentence treatment on offenders with substance abuse disorders.").

277. David Estes, Note, Kansas v. Hendricks as a Paradigm for Civil Commitment of Repeat Domestic Violence Offenders, 20 Thomas JEFFERSON L. Rev. 167 (1998). 
who poses a danger to himself, and police power, under which the state acts for the protection of the general public. In the case of substance abusers, neither of these rationales is convincing. Thus, given the fundamental importance of individuals' liberty interests under the Constitution, the civil commitment of substance abusers is unwarranted.

\section{A. The Fundamental Nature of Liberty}

The Fifth Amendment promises that no person shall be "deprived of life, liberty, or property, without due process of law."278 Freedom from physical restraint at the hands of the government has long been seen as a fundamental right, one that "has always been at the core of the liberty protected by the Due Process Clause from arbitrary governmental action."279 Thus, although an individual's liberty interest is not absolute, restraints on that individual's liberty in the civil context should only take place in narrow circumstances that coincide with legitimate justifications. ${ }^{280}$

\section{The Failure of the Criminal Act Rationale}

Those still in pursuit of the War on Drugs might point out that substance abusers have actually committed criminal acts just by using illegal substances. Thus, they could argue, confinement is appropriate, or at least permissible. There are several obvious responses to this.

First, the analogy fails because not all substance abusers use illegal drugs. At least one court found that chronic alcoholisn nuet the mental

278. U.S. CONST. amend. V. Similarly, the Fourteenth Amendment guarantees that "[n]o State shall ... deprive any person of life, liberty, or property, without due process of law."

279. Foucha v. Louisiana, 504 U.S. 71, 80 (1992); see also Jones v. United States, 463 U.S. 354, 361 (1983) ("It is clear that 'commitment for any purpose constitutes a significant deprivation of liberty that requires due process protection."') (citation omitted).

A detailed discussion of the requirements of Due Process in the context of civil commitment is beyond the scope of this paper. Several commentators have undertaken a constitutional analysis of Hendricks. See, e.g., Madelyn J. Daly, Comment, Do Sexually Violent Predators Deserve Constitutional Protections? An Analysis in Light of the Supreme Court's Ruling in Kansas v. Hendricks, 521 U.S. 346 (1997), 23 S. ILL. U. L.J. 715 (1999); Kimberly A. Dorsett, Note, Kansas v. Hendricks: Marking the Beginning of a Dangerous New Era in Civil Commitment, 483 DEPAul L. Rev. 113 (1998); Stephen R. McAllister, The Constitutionality of Kansas Laws Targeting Sex Offenders, 36 WASHBURN L.J. 419 (1997).

What is clear from these articles and others like thein is that there is substantial debate about whether the Supreme Court decided Hendricks correctly. While it is unlikely that the Court will overrule its own decision any time soon, it is possible that, given the opportunity, it will seek to narrow the decision. Thus, it is worthwhile to look at the rationale underlying the doctrine and consider how the Court might limit its decision should it be presented with new variations on the Hendricks paradign.

280. Hendricks, 521 U.S. at 356-57 (explaiming that every person is subject to certain restraints which are "for the common good," and that forcible detaimment is allowable in "certain narrow circumstances"). 
illness standard, ${ }^{281}$ and alcohol is correlated to even higher rates of violence than many illegal drugs. ${ }^{282}$ It is also worth noting that opinions differ as to which drugs really should be illegal; in the recent November 2000 election a number of voter referendums demonstrated that many Americans believe at least certain individuals should be able to use marijuana without fear of state repercussions. ${ }^{283}$

Additionally, even if one were to isolate those individuals who abuse substances more widely considered to be worthy of prohibition, such as heroin or crack, the chances of them actually being incarcerated for the offense of substance abuse if they were processed through the criminal justice system is slim. At least twenty-two states have or are in the process of implementing treatment-oriented drug courts ${ }^{284}$ which divert less serious offenders such as those facing possession or "under the influence" charges into treatment programs with extensive supervision by the court. ${ }^{285}$ Even when drug court is not an option, a sentence to probation is common for drug-abusing offenders. ${ }^{286}$ Thus, at least for the less serious crimes of possession and use, there is a good chance offenders will not serve time even if convicted.

More importantly, the criminal process offers significant due process protections to every defendant, such as the right to trial by jury, ${ }^{287}$ the right to cross-examine witnesses against him, ${ }^{288}$ conviction only by proof beyond a reasonable doubt, ${ }^{289}$ and the right to an attorney, appointed and paid for by the state where necessary. ${ }^{290}$ These provisions provide substantially greater opportunities for a defendant to protect his right to liberty, and thus make any analogy between civil and criminal proceedings unsound. If a state could get around the expense of criminal prosecutions merely by calling them civil commitments, the rights guaranteed to criminal

281. In re Smith, 692 P.2d 120, 122 (Or. Ct. App. 1984).

282. See Heilbrun \& Witte, supra note 243 and accompanying text.

283. See, e.g., B.J. Palermo, 2000 Election Produces Many New Criminal Laws: Sentencing, Drug Use, Guns Among the Initiative Topics of Interest to Practitioners, 23 NAT'L L.J., Nov. 20, 2000 at A10 (reviewing ballot initiatives that were successful in the November 7, 2000 election, including legalization of small marijuana farms in Mendocino County, CA, and legalization of possession and use of marijuana for medical purposes in Nevada and Colorado).

284. National Criminal Justice Reference Service, Drug Court Resources-Facts \& Figures, at http://www.ncjrs.org/drug_courts/facts.html.

285. National Association of Drug Court Professionals, Facts on Drug Courts, at http://www.nadcp.org/whatis/.

286. See Gregory P. Falkin et al., Matching Drug-Involved Probationers to Appropriate Drug Interventions: A Strategy for Reducing Recidivism, 63 Federal Probation 3, 3 (1999) (describing the large numbers of drug-involved offenders in probation and parole programs).

287. U.S. CONST. amend. V1 ("In all criminal prosecutions, the accused shall enjoy the right to a speedy and public trial, by an impartial jury ....").

288. U.S. CoNST. amend. V1 ("In all criminal prosecutions, the accused shall enjoy the right ... to be confronted with the witnesses against him ....").

289. See In re Winship, 397 U.S. 358 (1970).

290. See Gideon v. Wainwright, 372 U.S. 335 (1963). 
defendants would become moot. Thus, the argument that drug users are criminals, and therefore can be confined without the safeguards provided by the criminal justice system, fails.

\section{The Failure of the Parens Patriae or "They Need Treatment Anyway" Rationale}

It is common knowledge that substance abuse is a treatable condition. For this reason, one might attempt to justify the civil commitment of substance abusers on the grounds that commitment is for their own good. Such an argument would mirror the historical civil commitment rationale of parens patriae, under which the state acted as guardian of its incompetent citizens by confining and treating then. ${ }^{291}$ The parens patriae justification broke down when it became clear that the very reason for confinement, the provision of treatment, was failing miserably. ${ }^{292}$ But if it could be guaranteed that treatment would be provided, proponents of this rationale might argue, then it would be worthwhile to treat substance abusers, even against their will.

A response to the parens patriae rationale for the treatment of substance abusers begins with the "least restrictive alternative" principle. The Suprene Court enunciated the principle in Shelton v. Tucker: "In a series of decisions this Court has held that, even though the governmental purpose be legitimate and substantial, that purpose caunot be pursued by means that broadly stifle fundaniental personal liberties when the end can be more narrowly achieved." ${ }^{293}$ This concept has been discussed in detail as it applies to the civil commitment of inentally ill individuals, ${ }^{294}$ and it enjoys broad support; a majority of states recognize a right to the least restrictive treatment modality either by statute or through case law. ${ }^{295}$ The chief difficulty in protecting this right with respect to the mentally ill is the availability of the ideal treatment; where the least restrictive treatment is unavailable, some courts have held that a state is not required to provide it. ${ }^{296}$

In light of the least restrictive alternative principle, it is worth comparing the effectiveness of inpatient and outpatient treatment. Although the latter is obviously the less restrictive alternative, substance abusers confined against their will would by definition receive the former. In the recent

291. See supra Part I.A for a discussion of parens patriae.

292. See supra Part I.B.I.

293. 364 U.S. 479,488 (1960) (holding that a state statute requiring teachers to provide affidavits giving information about all organizations to which they had belonged or contributed within the preceding five years deprives thein of their rights to personal, associational, and academic liberty because such information exceeded the needs of the state in verifying the teacher's occupational competence or fitness).

294. See Hafemeister \& Amirshahi, supra note 200, at 84.

295. Parry, supra note 47 , at 324.

296. Id. 
age of managed care, substance abuse treatment providers have conducted a good deal of research and experimentation to determine the most costeffective methods of treatment. ${ }^{297}$ These studies have shown that when outpatient programs provide services similar to residential programs they can be comparably effective for many substance abusers. ${ }^{298}$ An Office of National Drug Control Policy research paper on treatment effectiveness recommended hospitalization of cocaine abusers only when the addiction coexisted with serious complications, such as "severe medical or psychiatric complications" or "severe psychosocial impairments," or where users have "failed in outpatient treatment." 299 Even under these extenuating circumstances, hospitalization can last for as little as three days. ${ }^{300}$

Moreover, some studies have shown substantial benefits to outpatient treatment, such as the ability of participants to maintain relationships with friends, family, and other support systems. Outpatient treatment can also be preferable because it "requires the patients to begin practicing the principles of recovery from the first day of treatment, because they continue to function in the world where they will need to stay sober after treatment." ${ }^{301}$ Finally, outpatient treatment is substantially less expensive than inpatient treatment. ${ }^{302}$ This means that, at least in jurisdictions with high volumes of substance abusers, it would be irrational for a state to argue that a less restrictive alternative is not available.

In light of the evidence that outpatient treatment can be effective for many substance abusers, and that constitutional protection of the fundamental interest in personal liberty requires use of the least restrictive alternative, the parens patriae rationale fails to justify civil commitment of substance abusers.

\section{The Failure of the Police Power Rationale}

Historically, the police power rationale for civil commitment took over where parens patriae left off. The justification under this theory, as seen in Hendricks, is that individuals may be civilly committed in the interest of "the common good" when they "pose a danger to the public health and safety." $"$ Although the Supreme Court did not limit its decision in Hendricks this way, ${ }^{304}$ there may be good reasons to believe that, in the

297. See, e.g., Jim Lohmeyer, Providing Needed Treatment Options in the Face of Managed Care, at http://www.treatment.org/TAPS/TAP17/tap17needed.html.

298. See National Institute on Drug Abuse, Principles of Drug Addiction Treatment, A RESEARCH-BASED GUIDE 27 (1999).

299. Office of National Drug Control Policy, Treatment Protocol Effectiveness Study, 1996, at http://www.whitehousedrugpolicy.gov/publications/treat/trmtprot.html.

300. Id.

301. Lohmeyer, supra note 297.

302. Id.

303. Kansas v. Hendricks, 521 U.S. 346, 357 (1997).

304. See supra Part II.A for a discussion of the holding. 
case of sexually violent predators, civil commitment is beneficial enough to the community to justify depriving them of their liberty ${ }^{305}$ However, because the benefit to the public of confining substance abusers is not nearly so obvious, police power is a weak justification for depriving them of their liberty.

The police power rationale is only legitimate to the extent individuals sought to be committed pose a danger to the public. It is clear that the traditional predictions of dangerousness used for civil commitment proceedings do not sufficiently limit the number of individuals potentially captured by the new mental abnormality standard. ${ }^{306}$ Still, some may argue that, because of the high correlation between substance abuse and crime, all substance abusers pose a substantial danger to the community.

It is true that there is a strong correlation between substance abuse and crime. In a 1997 survey, $19 \%$ of state prisoners and $16 \%$ of federal prisoners admitted to committing the offense for which they were serving time in order to get money for drugs. ${ }^{307}$ Even higher numbers of prisoners surveyed were under the influence of drugs at the time of their crime. ${ }^{308}$ Moreover, recidivism rates are extremely high among this population: according to the Department of Justice, over half (50.4\%) of those released from state prison in 1983 for drug offenses (including trafficking) were rearrested within three years. ${ }^{309}$

Even if one were willing to discard all the tenets of criminal procedure and declare that substance abusers are dangerous and therefore should be committed, there are further problems with the police power rationale. First, substance abuse is much more highly correlated with property crimes than with violent crimes. ${ }^{310}$ Still, arguably property crimes pose a danger to the community, and perhaps that would be sufficient justification to weigh in favor of committing substance abusers. More devastating to the police power argument is that the recidivism rate for substance abusers $(50.4 \%$

305. See supra note 9, discussing high recidivism rates of sexually violent predators.

306. See supra Part III.C for a discussion of the flaws of traditional dangerousness predictions.

307. U.S. Department of Justice, Bureau of Justice Statistics, Drugs and Crime Facts 5 (2001).

308. $22.4 \%$ of federal prisoners and $32.6 \%$ of state prisoners were under the influence of drugs at the time they committed their offenses. Office of National Drug Control Policy Fact SheEt: Drug-Related CRime 3 (2000).

309. Bureau of Justice Statistics Special Report, Recidivism of Prisoners Released in 19835 (1989). It should be noted that including trafficking in the category of drug offenses skews the statistics, since many traffickers are involved with drugs solely as a business and do not use the substances themselves. This category includes both international traffickers and street-level drug dealers. Thus, since statistics are generally not available on drug crimes committed only by those with addiction problems, it is important to recognize that the violence and recidivism levels for all drug offenders may be inflated by the inclusion of the trafficking population.

310. $17 \%$ of state prisoners overall admitted to committing their crimes in order to flnance drugs, but only $12 \%$ of violent offenders did so, compared to $27 \%$ of property offenders. OFFiCE of National Drug Control Policy Fact Sheet: Drug-Related Crime 3 (2000). 
overall) is actually lower than the rates for property offenders overall. An estimated $68.1 \%$ of property offenders were rearrested within three years. This included $69.6 \%$ of those convicted of burglary, and $78.4 \%$ of those convicted of auto theft. ${ }^{311}$

Thus, if the argument is that the correlation between substance abuse and crime is sufficient justification for exercising state police power to commit substance abusers, the same argument should apply equally to the civil commitment of anyone ever incarcerated for a property offense (assuming he could be found to have a mental abnormality). Not only would this be extraordinarily impractical, but the very idea of justifying the systematic incapacitation of all property offenders after they have been released from prison demonstrates the ability of the Hendricks rationale to quickly bridge the gap between police power and police state. ${ }^{312}$

In sum, although it appears that the possibility of civilly committing substance abusers is real and, at least under the current Court's view, constitutional, there are no legitimate justifications for such a policy. However, since such a policy recommendation may surface eventually, it is important to consider ways to prevent the implementation of such a policy or at least to mitigate its potential breadth.

\section{B. Some Suggestions for Mitigating the Problem}

The Hendricks decision has opened Pandora's box. However, it appears that legislatures have not yet seized on the expansion of the constitutional boundaries for civil commitment and altered their confinement provisions. Thus, there is room to minimize the damage and control the slippery slope at several levels of policymaking, including the U.S. Supreme Court, state judiciaries, and state legislatures.

\section{Judicial Options}

\section{a. The U.S. Supreme Court's Options}

The U.S. Supreme Court has the best opportunity to minimize the potential expansion of civil commitment laws, even without overruling Hendricks. In all likelihood, the Court will eventually receive a petition for certiorari in which "mental abnormality" is used in a statute not targeted at sexually violent predators or other similarly contemptible individuals. The

311. Bureau of Justice Statistics Special Report, Recidivism of Prisoners Released in 19835 (1989).

312. One author went so far as to compare preventive detention of suspected dangerous persons to the internment of Japanese-Americans during World War 11: "So long as some Japanese-Americans might engage in espionage, liberty could be denied to all within the targeted group." Grant $\mathrm{H}$. Morris, Defining Dangerousness: Risking a Dangerous Definition, $10 \mathrm{~J}$. CONTEMP. LEGAL Issues 61, 62 (1999). 
Court should grant review and use the opportunity to drastically narrow the scope of the Hendricks decision.

The best way for the Court to do this is to require that the broader statutory requirement of mental abnormality be used only in conjunction with a heightened standard of dangerousness, such as past criminal convictions for violent offenses, or insanity acquittals from similar charges. This would filter out individuals only "predicted" to be dangerous as well as those who have served time for non-violent offenses. At first glance, it might seem that defining dangerousness by prior conviction could be challenged on double jeopardy grounds. The Fifth Amendment guarantees that "no person shall...be subject for the same offence to be twice put in jeopardy of life or limb."313 Since by definition the proposed rule singles out prior convicts for committal, it could be argued that they are essentially being restrained after serving their sentence on the basis of the same crime. However, the Court rejected a similar challenge in Hendricks on the grounds that the Kansas Act was clearly civil in nature and therefore did not constitute a second prosecution or punishment. ${ }^{314}$

Although a complete reversal of Hendricks might be desirable, it is not likely to happen any time soon. ${ }^{315}$ However, even without reversing its Hendricks decision, the U.S. Supreme Court has substantial room to mitigate the potential damage Hendricks could cause by narrowing the earlier decision in future cases.

\section{b. State Judicial Options}

Although reversal by the U.S. Supreme Court is unlikely, state supreme courts also have the power to prevent egregious violations of due process rights by ruling that the broad "mental abnormality" standard approved by Hendricks violates rights guaranteed by state constitutions. It has long been a principle of federal court jurisdiction that the U.S. Supreme Court will only review federal questions; state supreme court decisions on state law are final. ${ }^{316}$ Thus, state courts are free to decide that, even if a statute like Kansas's survives the federal due process standard, it does not meet due process requirements under the state constitution. By framing their decisions as entirely within state constitutional law, state courts can escape review under the Hendricks precedent. ${ }^{317}$

313. U.S. ConsT. amend V.

314. 521 U.S. at 369.

315. The composition of the U.S. Supreme Court has remained constant since Hendricks. Moreover, given that Hendricks was decided by the standard conservative majority of Justices Thomas, Rehnquist, O'Connor, Scalia, and Kennedy, any change in the composition of the Court while President Bush is im office will be unlikely to push a decision in the opposite direction.

316. Murdock v. City of Meuphis, 87 U.S. (20 Wall.) 590 (1874).

317. State supreme courts occasionally offer greater protections under their state constitutions than would be applicable under the federal constitution. For example, in People v. Disbrow, the California Supreme Court interpreted that state's constitution to preclude a prosecuting attorney from using 
Short of declaring statutes unconstitutional, state courts can also undermine the impact of broad civil commitment legislation by requiring that the states actually provide the treatment technically required by the statutes. Hendricks observed that "the State has a statutory obligation to provide 'care and treatment for [persons adjudged sexually dangerous] designed to effect recovery," but excused the "meager" treatment Hendricks received on the grounds that he was the first person committed under the statute, and thus the state may not have had all of it treatment procedures in place. ${ }^{318}$ State courts need not make such exceptions; they have the power to release individuals if the state does not meet its obligations. Although such action by courts would not alter the legislation, it would at least ensure that confined individuals received effective treatment; this would serve to distinguish civil commitment from criminal incarceration and, if the individual participated and improved, it could also diminish the time of confinement. Moreover, because providing legitimate treatment is costly, such a requirement would likely serve to limit the use (abuse) of these statutes as a way to confine people without the constitutional restrictions that are placed on criminal prosecution.

\section{State Legislative Options}

Of course, if state legislatures decline to take the U.S. Supreme Court up on its offer to allow expansion of involuntary confinement many of these problems will never surface. After Hendricks, legislatures appear to have the power to define their civil commitment statutes any way they choose, and they can narrow them as much as they want. Legislatures should work with mental health professionals to design statutory guidelines for civil commitment that are consistent with the state's ultimate goal of providing for the safety of its citizens while maintaining the least restrictive police state possible. Because courts apparently will not require legislatures to narrow their confinement statutes, individuals and lobbying organizations must get involved to let legislators know they do not support unrestrained confinement. The mental health professional community has

statements made by the defendant without Miranda warnings for impeachment purposes, despite a U.S. Supreme Court case finding such use permissible under the U.S. Constitution. 545 P.2d 272, 280 (1976). Similarly, at least two state supreme courts, in Connecticut and Oklahoma, have held that education is a fundamental right protected by state equal protection clauses, notwithstanding the U.S. Supreme Court's holding in San Antonio Independent School District v. Rodriguez, that education is not protected by the Fourteenth Amendment's Equal Protection Clause. See Bill Swinford, Shedding the Doctrinal Security Blanket: How State Supreme Courts Interpret Their State Constitutions in the Shadow of Rodriguez, 67 TeMP. L. Rev. 981, 1000 (1994). In fact, in a 1977 law review article, Supreme Court Justice William Brennan applauded and encouraged this type of state court activism. See William J. Brennan, Jr., State Constitutions and the Protection of Individual Rights, 90 HaRv. L. REV. 489 (1977).

318. 521 U.S. at 367-68 (alteration in original) (citations omitted). 
consistently argued against commitment laws like the one upheld in Hendricks. ${ }^{319}$

\section{CONCLUSION}

The U.S. Supreme Court set a dangerous precedent in Kansas $v$. Hendricks when it refused to safeguard individuals' constitutionally protected rights to liberty. In a case indicative of the old adage that bad facts make bad law, the Court, without any justifiable rationale, turned a statute aimed at keeping sexually violent predators out of the community into an invitation for states to involuntarily confine almost anyone they see fit. If states accept this invitation, the liberty interests of substance abusers will be at substantial risk. The U.S. Supreme Court ought to take the first opportunity to narrow its holding. Absent such action, state legislatures and judiciaries should be aware of the potential for violation of individuals' constitutionally protected right to liberty and take steps to safeguard those rights. 
